\title{
Correlative Histological and Umami Taste Assessment Study of Gustatory Papillae on the Dorsal Lingual Mucosa in Different Original Animal Species
}

Article

Fatma Adel Saad, Rehab A. Abdel Moneim and Mona El Deeb

Oral Biology Department, Faculty of Dentistry, Future University, Egypt

\begin{abstract}
Background: A correlative characterization of oral mucosa was carried out in common animal species. Objective: This work aimed to correlate the histological structure of lingual gustatory papillae as well as the immunohistochemical reactivity to a particular umami receptor among different animal species to categorize the best experimental animal models for research.

Methods: The dorsal lingual mucosal specimens were obtained from four species (orders) including; chicken (Galliformes), frogs (Anura), camels (Artiodactyla) and rabbits (Lagomorpha). They were processed for routine histological examination; histochemical staining using periodic acid Schiff (PAS) and Masson's trichrome in addition to immunohistochemical localization of umami metabotropic glutamate receptor-4 (mGluR4) antibody.

Results: Chicken, camels and rabbits exhibited keratinized stratified epithelium on the dorsal lingual mucosa with statistically greatest thickness in anterior lingual epithelium of chicken. For frogs, filiform and fungiform papillary walls were formed of mucous secreting columnar monolayer epithelium with a subjacent spindle cell layer. Insignificant differences in PAS staining intensity of dorsal lingual epithelium were noted between chicken anteriorly and rabbits as well as between chicken posteriorly and camels with the greatest significant intensity in frogs reflecting the highest content of glycogen and mucin. Likewise, the density of lamina propria and degree of collagen fibers bundling detected by Masson's trichrome were significantly different among species greatest in chicken and least in frogs. Intraepithelial taste buds were found in chicken while frogs displayed on top of fungiform papillae the largest gustatory disc among vertebrates. Camels and rabbits presented conventional papillary taste buds with the absence of foliate papillae in camels. Chicken and camel were negatively immunoreacted to mGluR4; frogs and rabbits were positively immunoreacted with the strongest reaction in rabbits.

Conclusion: It was concluded that the direct association between histological variations of masticatory lingual mucosa and diverse environmental factors would reflect the adaptation capability of the lingual tissue.
\end{abstract}

Received: 02 October 2019, Accepted: 26 October 2019

Key Words: Camel, chicken, frog, mGluR4, rabbit.

Corresponding Author: Fatma Adel Saad, PhD, Oral Biology Department, Faculty of Dentistry, Future University, Egypt, Tel.: +20 1223739140, E-mail: femy76@hotmail.com

ISSN: $1110-0559$, Vol. 43, No. 1

\section{INTRODUCTION}

Feeding mechanism is significant to determine the adaptation of vertebrates to their environment. Tongue; the movable musclomembranous organ is considered as key for this adaptation. The tongue size and structure reveal strong correlation between tongue features and functional variations ${ }^{[1,2]}$. Tongue is specialized to accomplish different functions and has been studied for its relation to taste sensation. The functional variations are directly associated with dietary specializations, feeding habits and with adaptations to various environmental conditions ${ }^{[3,4]}$. Tongue papillae are responsible for directing both ingested food and liquids to taste buds. The anterior part shows filiform papillae which possess mechanical function. Fungiform, vallate and foliate papillae are related to gustatory function $^{[5]}$. Morphological and histological structures of lingual papillae are species-specific and regions specific in the same animal to be consistent with the masticatory and gustatory needs ${ }^{[1,6,7]}$.

Umami taste is one of the basic taste qualities (sweet, bitter, sour, and salty). Umami is a meaty, earthy, mouth-filling rich taste found in many types of food as seafood, meat, tomato and mushrooms. It is also elicited by various small molecules including nucleotides as monosodium glutamate (MSG) and amino acids as glutamate and aspartate. Multiple umami receptors are involved in the perception of umami taste sensation; named as brain-types metabotropic glutamate receptors (brain-mGluR1, brain-mGluR4), taste-mGluR1, taste-mGluR4 as well as T1R1/T1R3 ${ }^{[8]}$.

Chicken (Aves: Galliformes) tongues exhibit morphological and structural adaptations to distinct eating habits and lifestyle ${ }^{[9]}$. Scarce evidences for the 
expression of taste-related genes and receptors in gustatory or extragustatory tissues of chickens are elucidated ${ }^{[10]}$. Few details are available about surface structure of the frog (Amphibia: Anura) tongues. However, it was stated that the anuran tongue contains two types of papillae that are believed to function in secretion of salivary fluid and in gestation ${ }^{[11,12]}$. One-humped or Arabian camels (Mammalia: Artiodactyla) lives in regions of dry climate with high temperature and feed on thorny plants with rough hard stems. Thus, the camel's oral cavity is so sturdy with special characteristics for ease feeding and taste functions ${ }^{[6]}$. Moreover, rabbit (Mammalia: Lagomorpha) exhibits modified tongue and teeth as an adaptation to herbivorous diet. Therefore, it is given a separate order because of the dentition differences; mostly incisors ${ }^{[3,13,14]}$. Accordingly, the aim of this work was to unveil the histological and histochemical differences of dorsal lingual epithelium, gustatory papillation and taste buds as well as the immunohistochemical reactivity of taste cells to the umami mGluR4 in various animal orders to sort the best experimental animal models for research.

\section{MATERIALS AND METHODS}

\subsection{Ethical statement}

The experimental design was approved by Cairo University Institutional Animal Care and Use Committee (CU-IACUC) Medical Science Sector.

\subsection{Study design}

The study was carried on different adult male animal species; rabbits (Oryctolagus cuniculus), camels (Camelus dromedarius), chicken (Gallus domesticus) and frogs (Neobatrachia Bufonid). Animals were collected under supervision of specialized veterinarians. Tongues of camels, chicken and rabbits were obtained from Cairo slaughter house, El Basateen. Tongues of frogs were collected from students' labs, Faculty of science, Cairo University. Five tongue specimens were obtained from each animal species. All collected tongue specimens were immediately fixed in $10 \%$ neutral formalin and processed for histopathological and immunohistochemical staining. For chicken ${ }^{[15]}$ and frogs ${ }^{[12]}$; the tongues were placed as a whole. While for camels $^{[16]}$ and rabbits ${ }^{[3]}$, the tongues were further excised according to the anatomical location of different papillae.

\subsection{Histopathological Examination}

The specimens were fixed in $10 \%$ neutral formalin for 48 hours, dehydrated in alcohol, cleared in xylene and embedded in paraffin. Sections of $4-5 \mu$ thickness were mounted on regular glass slides to be stained by Hematoxylin and Eosin (H\&E) for histological examination, Periodic acid- Schiff stain (PAS) and Masson's trichrome stain for detection of polysaccharides and collagen fibers respectively ${ }^{[17]}$.

\subsection{Immunohistochemistry (IHC)}

For IHC examination, 4-5 $\mu \mathrm{m}$ paraffin embedded sections were mounted on positively charged optiplus slides. After washing with $1 \%$ phosphate-buffered saline (PBS) three times for $5 \mathrm{~min}$., the slides were immersed in $30 \% \mathrm{H}_{2} \mathrm{O}_{2}$ in methanol at room temperature for 15 $\mathrm{min}$. They were treated with proteinase $\mathrm{K}(20 \mu \mathrm{g} / \mathrm{ml})$ and incubated in a humidified chamber at $37^{\circ} \mathrm{C}$ for $15 \mathrm{~min}$. for antigen retrieval. The slides were then boiled with $0.1 \mathrm{M}$ citrate buffer $(\mathrm{pH} 6.0)$ in a microwave oven for $10 \mathrm{~min}$. and left at room temperature for $20 \mathrm{~min}$ to cool down. After washing with PBS, the primary antibody against mGluR4 (Polyclonal, Rabbit Anti-mGluR-4, United States Biological | 4 Technology Way | Salem, MA 01970) was applied to the tissue sections. After washing with PBS, labeling was done using the streptavidinbiotin immunoperoxidase method with a commercial kit (LSAB kit, DAKO, USA). Tissues were visualized using diaminobenzidine (DAB) as a chromogene to produce a nuclear and/or cytoplasmic brown color. Counterstaining was performed with Mayer's hematoxylin ${ }^{[8,18]}$. The sections were then examined using Olympus light microscope equipped with digital camera for histological evaluation.

\subsection{Histomorphometric analysis}

Leica microscope with digital camera and software (Leica Qwin 500) was used for image analysis. The image analyzer changes the pixels created with the image analysis program to real micrometer units. For each specimen, the structure of dorsal lingual mucosa obtained from each species was analyzed in respect to ${ }^{[1]}$ thickness of epithelium ${ }^{[2]}$, density of collagen fibers (lamina propria) $^{[3]}$, affinity of epithelial cells to $\mathrm{PAS}^{[17]}$ in addition to the reaction intensity to anti-mGluR4.

\subsection{Statistical analysis}

All obtained data from histopathological examination and immunohistochemical expression of mGluR4 in dorsal lingual mucosa and gustatory papillae were analyzed using Statistical Package for Social Science software computer program version 23 (SPSS, Inc., Chicago, IL, USA). Data were presented in mean and standard deviation. One way Analysis of variance (ANOVA) and Tukey were used for comparing data. $P$ value less than 0.05 was considered statistically significant ${ }^{[18]}$.

\section{RESULTS}

\subsection{Histopathological Results}

\subsubsection{Chicken}

The dorsal surface of the chicken's tongue could be divided into apex, body and root. The apex and body were covered with thick keratinized stratified squamous epithelium that showed more or less flat epithelial ridges. The keratin layer appeared thick forming microridges particularly in the area of the body (Figures 1 and 2). More posteriorly, there was apparent thinning of both epithelium and keratin with absence of the characteristic microridges (Figures 3 and 4). No gustatory papillae were detected. However, numerous intraepithelial taste buds were revealed anteriorly more than in the root. They assumed 
circular or polygonal outline and exhibited an elongated taste canal in some specimens (Figure 2). Some of which could be detected more superficial with their taste pores opening onto the surface epithelium (Figure 4).

The lamina propria (LP) appeared highly vascularized with thick walled often congested blood vessels and densely packed collagen fibers particularly in the posterior region (Figures 1-4). In the tongue apex, LP appeared devoid of glands or skeletal muscle fibres (Figure 1). Yet, anterior and posterior lingual glands were noticed assuming a compound tubular pattern (Figures 2 and 3) together with many lymphocytes (Figure 4). Anteriorly, the epithelium lining of the glandular tubules exhibited an irrgular, branching and widened lumen (Figure 2). While, in the lingual root; typical mucous acini were detected (Figure 3). A well defined core of hyaline cartilage could be differentiated subjacent to LP; particularly in the tongue apex (Figure 1).

\subsubsection{Frog}

The dorsal surface of the frog's tongue exhibited an irregular outline with filiform and fungiform papillae. Filiform papillae were numerous and distributed over the entire surface; with the fungiform papillae scattered among them. Filiform papillae appeared as high, narrow, rod like structures arranged as parallel clefts (Figure 5). The fungiform papillae (gustatory papillae) displayed an inverted cone form with a very narrow base and wide surface. Simple columnar non ciliated epithelium formed the filiform papillae and fungiform papillary walls. A discontinuous layer of spindle-shaped cells was observed immediately beneath the basement membrane (Figures 5 and 6). On approaching the fungiform surface, the frog's taste organ could be distinguished on top as a round thickened taste disc (TD). The TD was composed of pluristratified epithelium with apical layer of mucous cells forming the dome of the papillae (Figure 6). The LP was nearly obscured by heavy masses of muscle fibers intervening among and beneath the numerous lingual glands. These glands assumed an irregular outline with widened lumen which was sometimes with stagnant secretion. In some sections, the glands were associated with accumulated lymphoid cells (Figure 7). The connective tissue (CT) core was composed of sparse collagen fibers and capillary loops with a convoluted course (Figures 5 and 6).

\subsubsection{Camel}

Histological observations showed that the dorsal surface of camel's tongue revealed fungiform and circumvallate gustatory papillae. In comparison to other smaller mammals; the camel's papillae exhibited a huge size. No foliate papillae could be detected. The fungiform papillae assumed mushroom like appearance with narrow base and smooth rounded top and were lined by keratinized stratified squamous epithelium with few intraepithelial taste buds along their dorsal surface. The LP was composed of collagen fibers with dispersed muscle fibers (Figure 8).
The gigantic circumvallate papillae were covered with keratinized stratified squamous epithelium. The keratin layer on the surface appeared thicker than that covering the fungiform; however, gradual thinning along the walls was revealed. Numerous taste buds could be observed along the medial papillary walls. A wide, deep trough was noted separating the papilla from the tongue surface. The dorsal epithelial covering of the tongue appeared with apparently long epithelial ridges. The large irregular CT core displayed high cellularity and numerous, irregular secondary papillae (Figure 9). Lingual glands of seromucous type appeared at the bottom of the trough (Figure 10).

\subsubsection{Rabbit}

Microscopic findings of the rabbit's dorsal lingual surface revealed fungiform, circumvallate and foliate gustatory papillae. The fungiform papillae displayed narrow base and broad rounded top with keratinized stratified squamous epithelium. One or two oval taste buds could be detected on their dorsal surface. The dorsal epithelial covering of the tongue showed epithelial ridges of apparent moderate length (Figure 11). Circumvallate papillae exhibited round to oval-shape with narrow base and smooth rounded top and were surrounded by a typical trough. The covering keratin extended along their lateral borders till the depth of the trough. Some papillae displayed slight surface irregularity simulating microridges. They also showed numerous oval taste buds on their lateral walls. The CT revealed high cellularity, vascularity with multiple secondary papillae. Masses of serous and mucous acini were evident in LP at the base of circular furrow intermingled with the muscle bundles in submucosa (Figure 12).

Multiple foliate papillae appeared as leaf-like parallel ridges on the posterolateral margin. A thin layer of keratin was observed lining the lateral walls facing the trough with numerous taste buds. The covering epithelium invaginated forming two well developed epithelial streaks. Desquamated epithelial cells could be observed scattered on the surface. Pure serous lingual glands could be detected in the submucosa intervening with muscle bundles (Figure 13).

\subsection{Histochemical Results}

\subsubsection{Periodic Acid Schiff (PAS)}

Histochemical results of PAS reaction revealed variable intensity within the four studied species. Positive PAS staining of the keratinized epithelial surface was observed in chicken, camel and rabbit in all examined mucosal sections except for the non keratinized papillary surface of the rabbit foliate papillae. The reaction was noted clearly in basal, parabasal cell layers and in the superficial cell layers of all species but frog. The highest staining intensity was related to the frog particularly among the lingual glands and cells of the TD. Camel and chicken demonstrated weak to moderate PAS +ve staining. Most of rabbit sections exhibited higher staining when compared to 
camel. However, the lingual glands of the posterior portion of the chicken's tongue showed heavy staining intensity (Figure 14).

\subsubsection{Masson's Trichrome stain}

Masson's Trichrome stain showed different collagen fibrous distribution among the studied species. Regarding the chicken's tongue; densely packed collagen fibers could be detected beneath the basement membrane of the anterior portion as a thin rim of deep blue color. More posteriorly, the fibers exhibited a network configuration surrounding the mucous glands. In the superficial layer of the submucosa, the collagen fibers were faintly stained and widely dispersed. Unlike chicken; collagen fibers distribution in the frog's tongue displayed less staining intensity. Yet, numerous red muscle fibers were evident among the faintly stained fibers. Camel and rabbit specimens revealed nearly similar moderate intensity and distribution of the stain in lamina propria and surrounding the intensely stained lingual muscles in the rabbit's tongue (Figure 15).

\subsection{Immunohistochemical Results}

Immunohistochemical results of the studied species revealed negative immune reaction of the chicken and camel lingual epithelia to anti-metabotropic glutamate receptor 4 (mGluR4). Moderate immune reactivity was evident among the cells of the TD in frog. As for the rabbit, moderate to strong immunoreaction was noted particularly within the taste buds. The taste buds of the foliate papillae displayed the strongest immune reaction in relation to the fungiform where moderate reactivity was evident, and the circumvallate papillae exhibited the least reaction (Figure 16).

\subsection{Statistical results}

Regarding epithelial thickness; a statistically significant variation was illustrated among the species. The anterior lingual epithelium of chicken exhibited the greatest thickness; while the frogs' specimens were the thinnest. The camels' epithelium appeared thicker than rabbits and posterior lingual epithelium of chicken respectively (Table I, Figure 17). Statistical significance of PAS staining intensity was demonstrated within frogs' specimens, the anterior lingual epithelium of chicken, rabbits' specimens, posterior lingual epithelium of chicken and camels' epithelium in descending manner. Likewise, insignificant differences were noted between rabbit and chicken anterior lingual epithelium as well as between camel and chicken posterior lingual epithelium (Table II, Figure 18). Statistical Masson trichrome results elucidated that density of collagen fibers in lamina propria was more pronounced in chicken $>$ camels $>$ rabbits $>$ frogs with significant differences among all species (Table III, Figure 19). Statistically, the strongest reaction to anti-mGluR4 appeared in the rabbits' papillae where foliate $>$ fungiform $>$ circumvallate papillae. Significant variations in mGlur4 reaction among the different rabbit papillae were revealed and also between rabbits and frogs gustatory systems (Table IV, Figure 20).

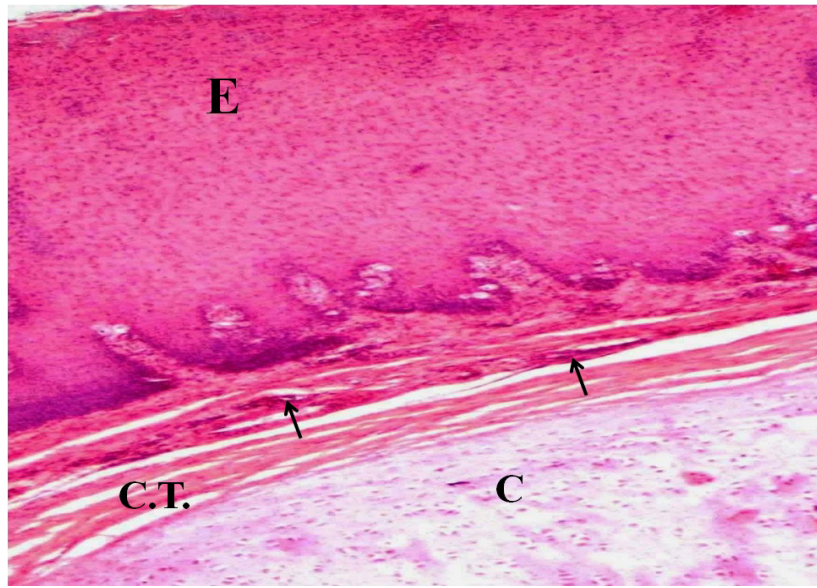

Fig. 1: A Photomicrograph of the apex of the chicken's tongue showing; thick stratified squames epithelium (E) with keratin, connective tissue forming lamina propria(C.T.), blood vessels (arrows) and hyaline cartilage (C) (H\&E, Orig. Mag. 100)

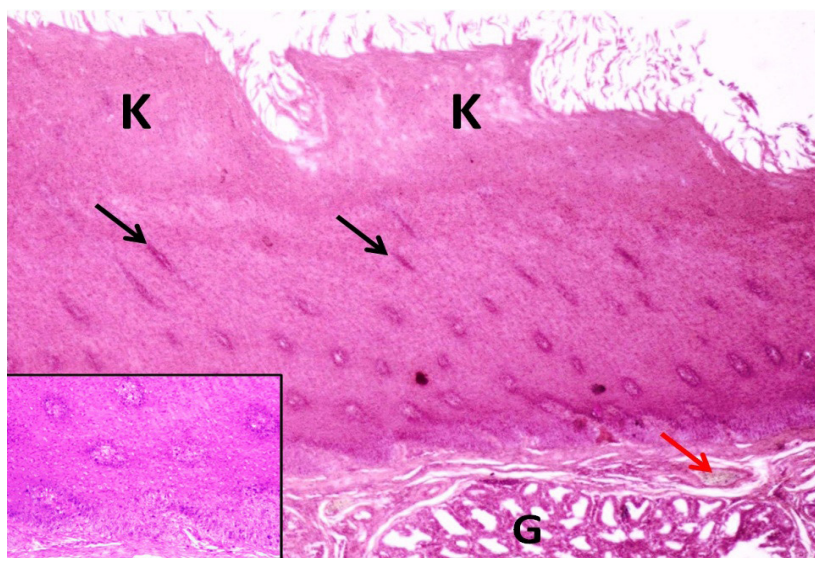

Fig. 2: A Photomicrograph of the body of chicken's tongue showing; keratin forming microridges $(\mathrm{K})$, taste buds with taste canals (black arrows), thick walled blood vessels (red arrow), branching lingual glands (G) (H\&E, Orig. Mag. 100). Inset: Higher magnification showing; circular or polygonal taste buds (H\&E, Orig. Mag. 200)

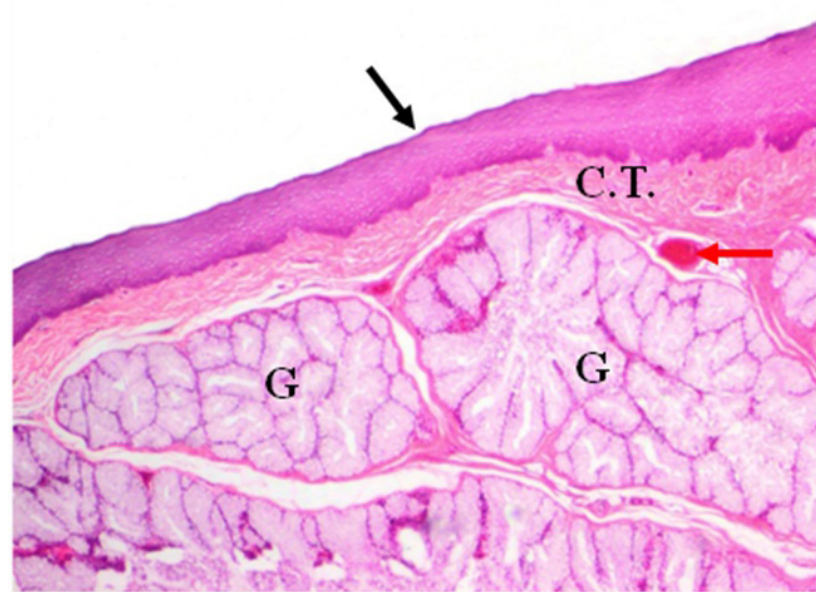

Fig. 3: A Photomicrograph of the root of chicken's tongue showing; flat epithelial surface (black arrow), congested blood vessels (red arrow), collagen fibers (C.T.) and mucous acini (G) (H\&E, Orig. Mag. 40) 


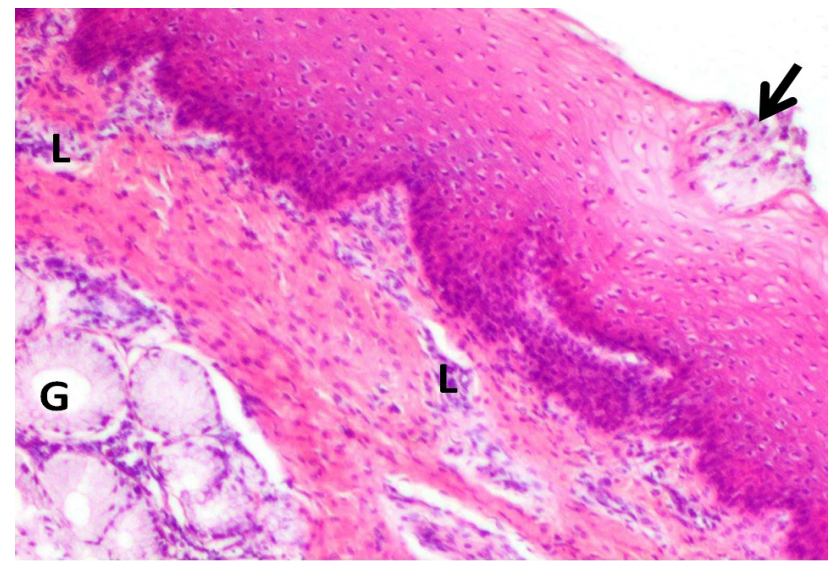

Fig. 4: Higher magnification of the root of chicken's tongue showing; lymphocytes (L), a superficial taste bud with its pore(arrow) and lingual glands (G) (H\&E, Orig. Mag. 100)

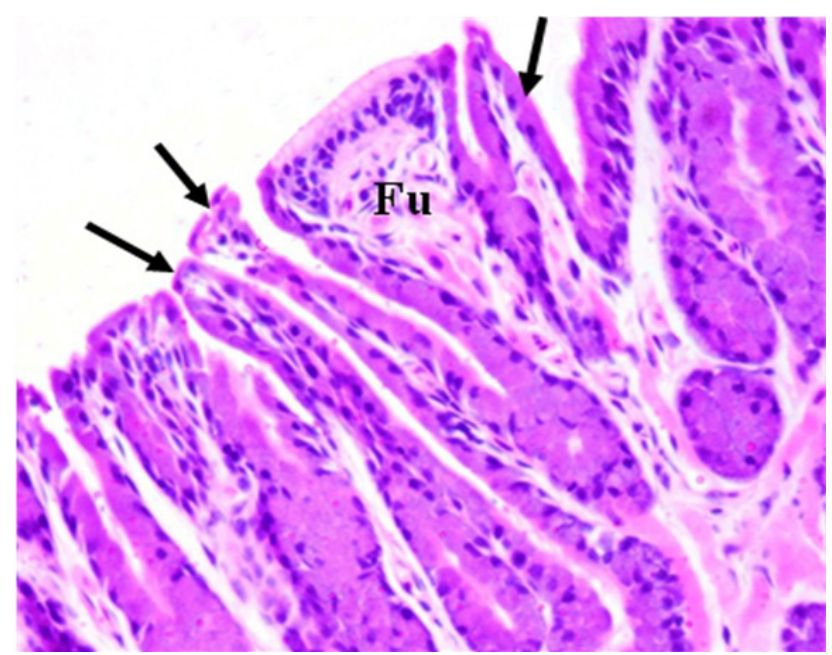

Fig. 5: A Photomicrograph of the dorsal surface of frog's tongue showing; filiform papillae (arrows), fungiform papillae ( $\mathrm{Fu})$ (H\&E, Orig. Mag. 200)

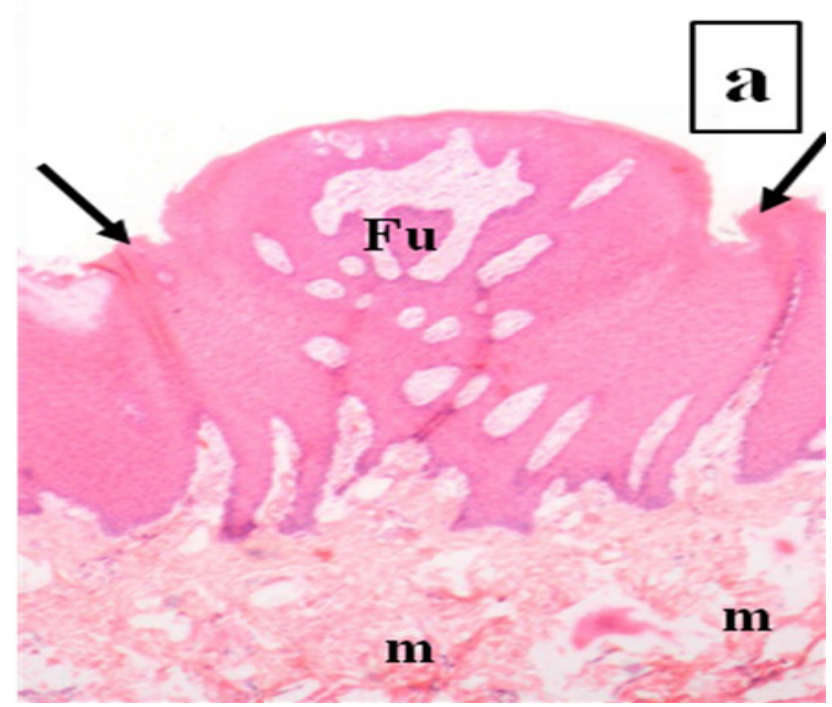

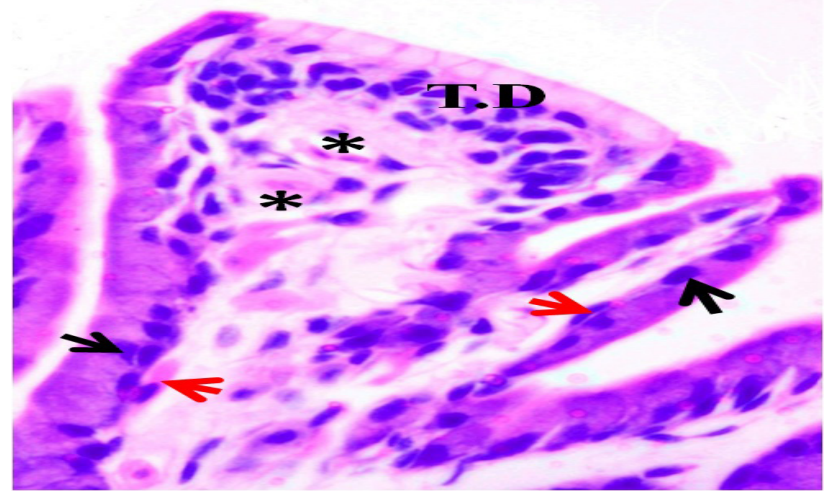

Fig. 6: Higher magnification of frog papillae showing; taste disc (T.D) on top of fungiform papilla, monocolumnar epithelial layer forming walls of filiform and fungiform papillae (black arrows), subepithelial spindle cell layer (red arrows) and blood capillaries (asterisks) (H\&E, Orig. Mag. 400)

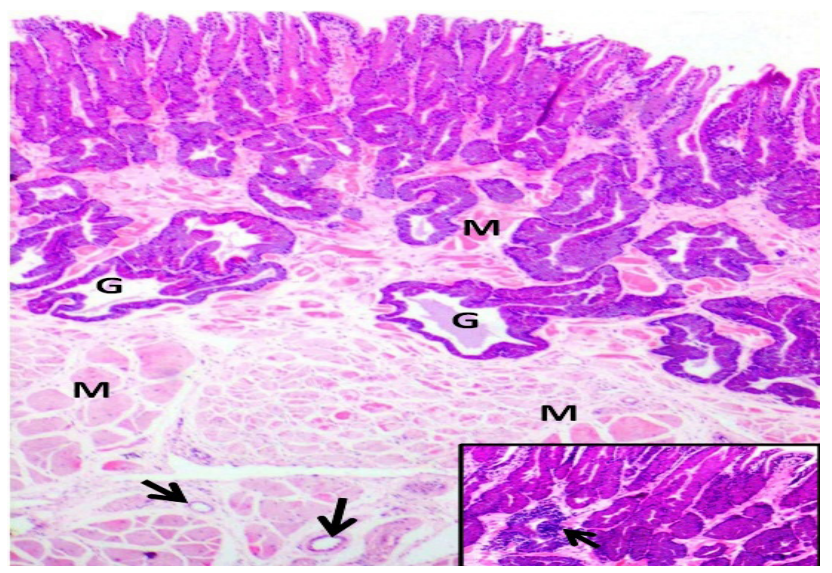

Fig. 7: A Photomicrograph of the the dorsal surface of frog's tongue showing; muscle fibers $(\mathrm{M})$, irregularly shaped glands with stagnant secretion $(\mathrm{G})$ and blood vessels (arrows) (H\&E, Orig. Mag. 40). Inset: Lymphoid cells associated with the glands (arrow) (H\&E, Orig. Mag. 100)

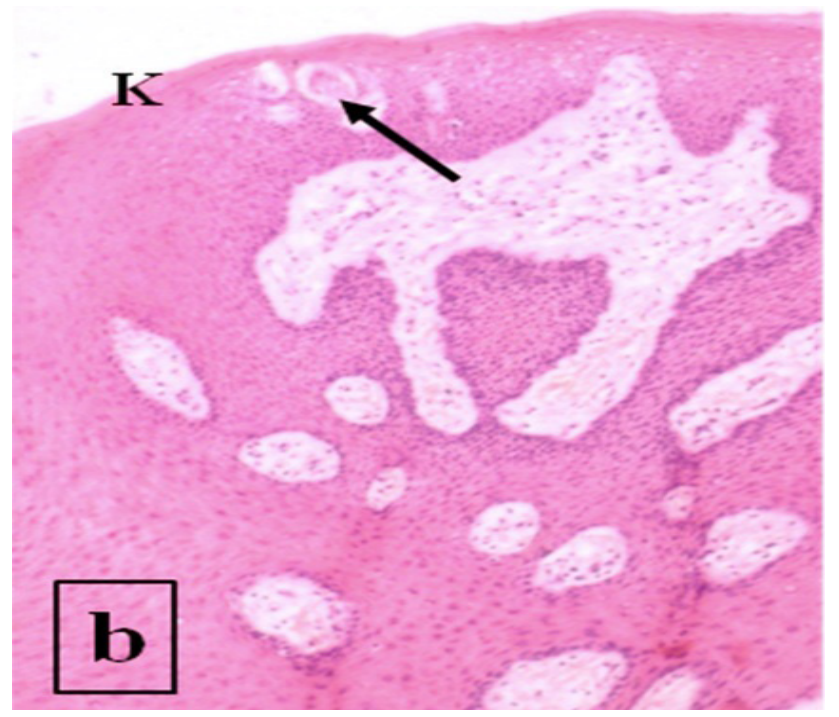

Fig. 8: Photomicrographs of the the dorsal surface of camel's tongue showing;

(a): Fungiform papillae (Fu), filiform papillae (arrows), lamina propria and muscle fibers (m) (H\&E, Orig. Mag. 40).

(b): Higher magnification showing; keratinized epithelium (K), taste buds (arrow) (H\&E, Orig. Mag. 100) 

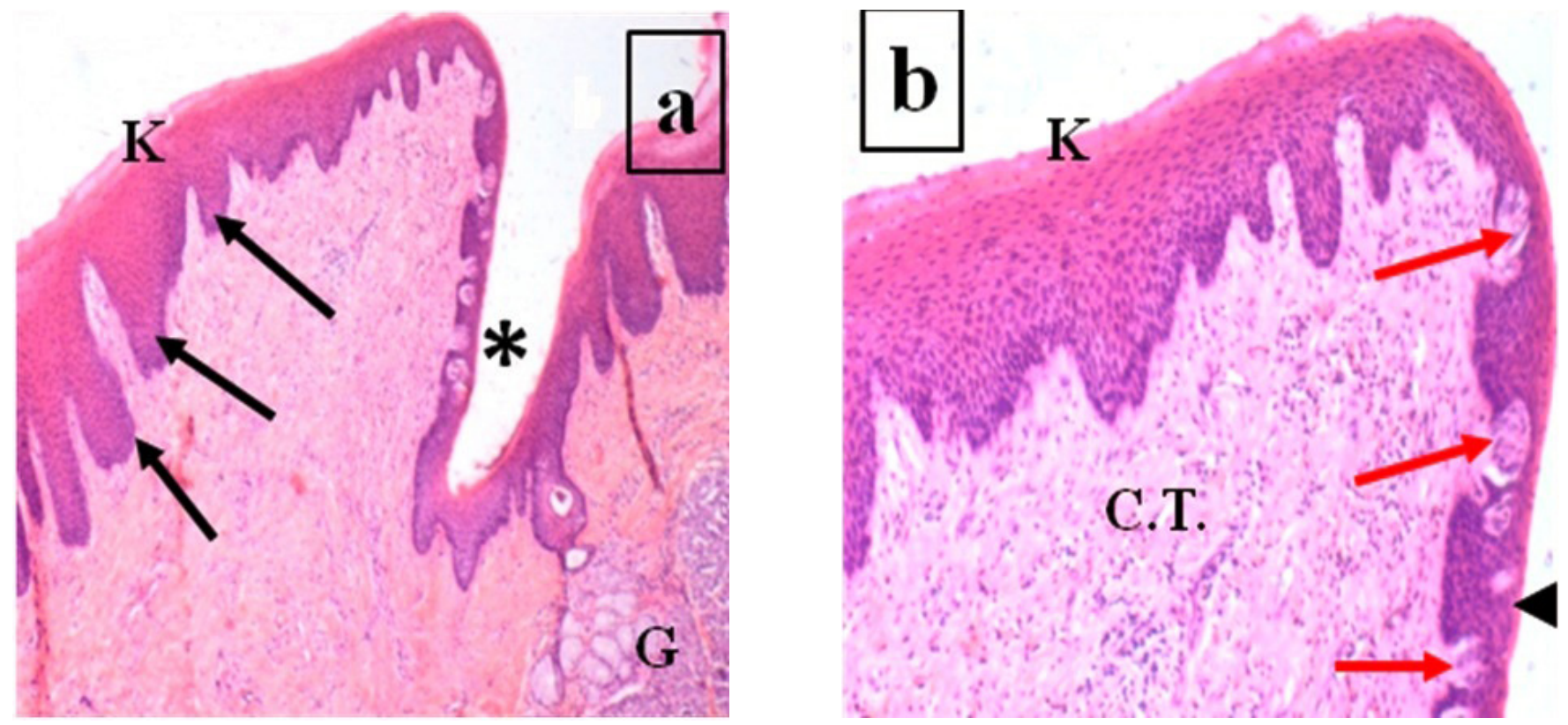

Fig. 9: Photomicrographs of the the dorsal surface of camel's tongue showing;

(a): Circumvallate papilla covered with keratinized epithelium(K), papillary trough(asterisk), lingual glands(G), secondary papillae(arrows) (H\&E, Orig. Mag. 40).

(b): Higher magnification showing; thick keratin layer(K) with thinning along the walls(arrowhead), taste buds(arrows) and connective tissue core(C.T.) (H\&E, Orig. Mag. 100)

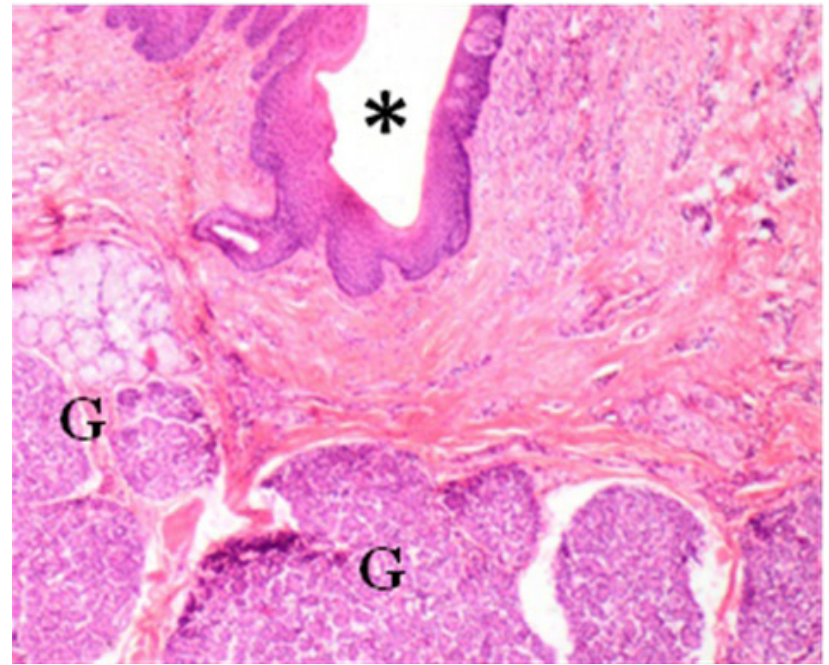

Fig. 10: A Photomicrograph of the the dorsal surface of camel's tongue showing; lingual glands $(\mathrm{G})$ at the bottom of the trough(asterisk) (H\&E, Orig. Mag. 40)

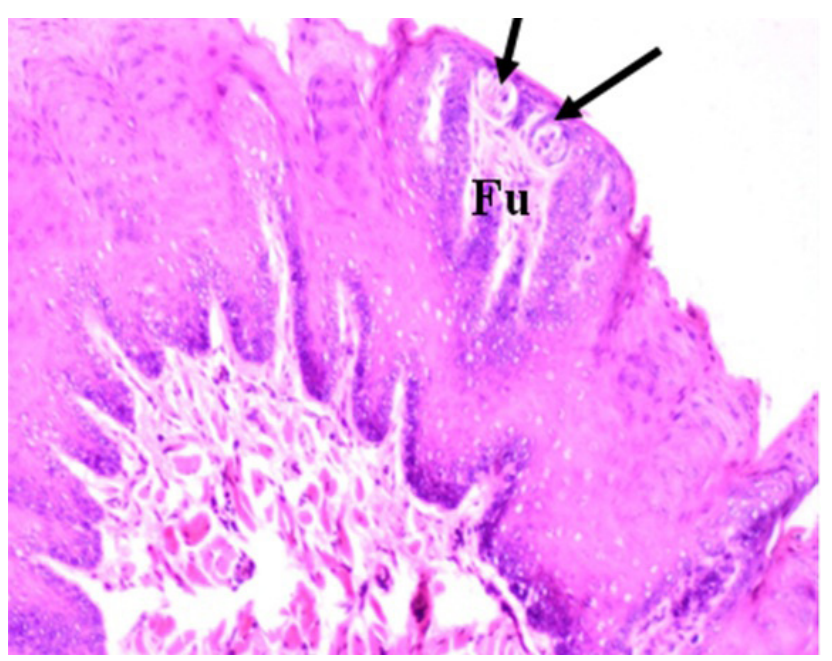

Fig. 11: A Photomicrograph of the the dorsal surface of rabbit's tongue showing; fungiform papillae $(\mathrm{Fu})$, taste buds (arrows) (H\&E, Orig. Mag. 100) 

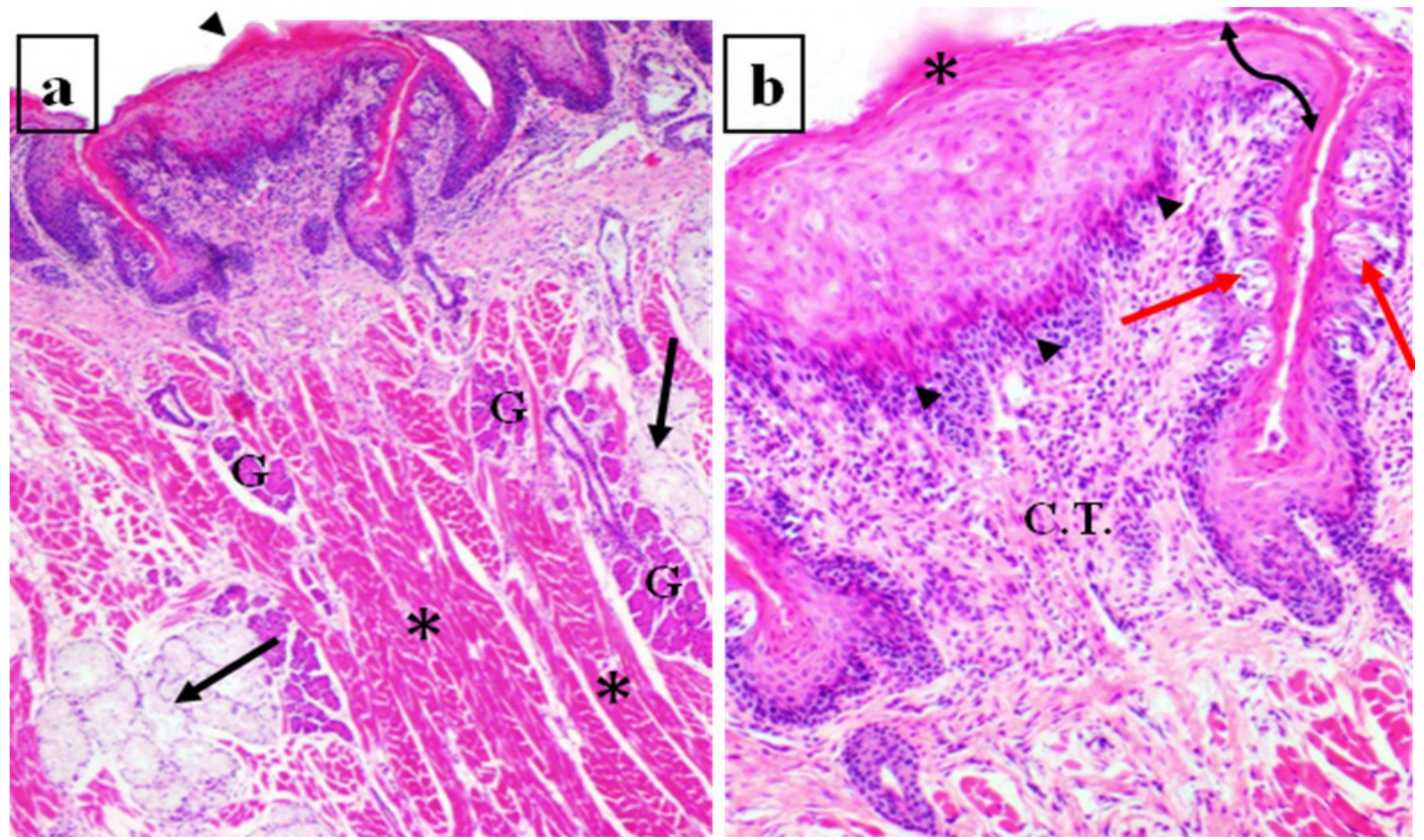

Fig. 12: Photomicrographs of the the dorsal surface of rabbit's tongue showing;

(a): Circumvallate papillae with epithelial microridges (arrowhead), serous acini (G), mucousacini (arrows), muscle bundles (asterisks) (H\&E, Orig. Mag. 40)

(b): Higher magnification showing; keratinized epithelium (curved arrow), epithelial microridges (asterisk), taste buds (red arrows), connective tissue (C.T.), secondary papillae (arrowheads) (H\&E, Orig. Mag. 100).
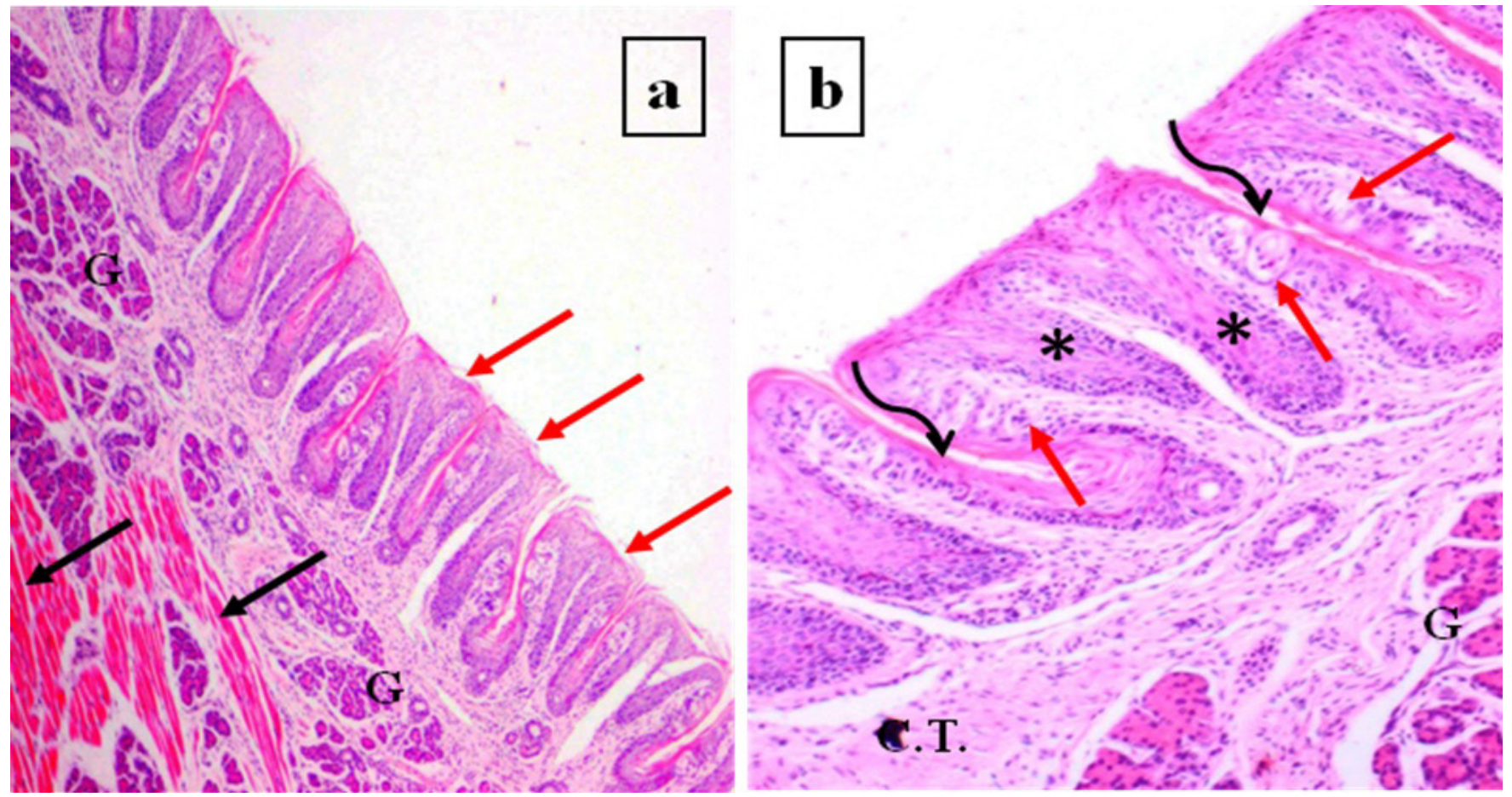

Fig. 13: Photomicrographs of the dorsal surface of rabbit's tongue showing;

(a): Foliate papillae with desquamated epithelial cells (red arrows), lingual glands (G), dense muscles (black arrows) (H\&E, Orig. Mag. 40). (b): Higher magnification showing; keratin lining the lateral walls facing the trough (curved arrows), taste buds (red arrows), loose connective tissue (C.T.), epithelial streaks (asterisks), lingual glands (G) (H\&E, Orig. Mag. 100). 

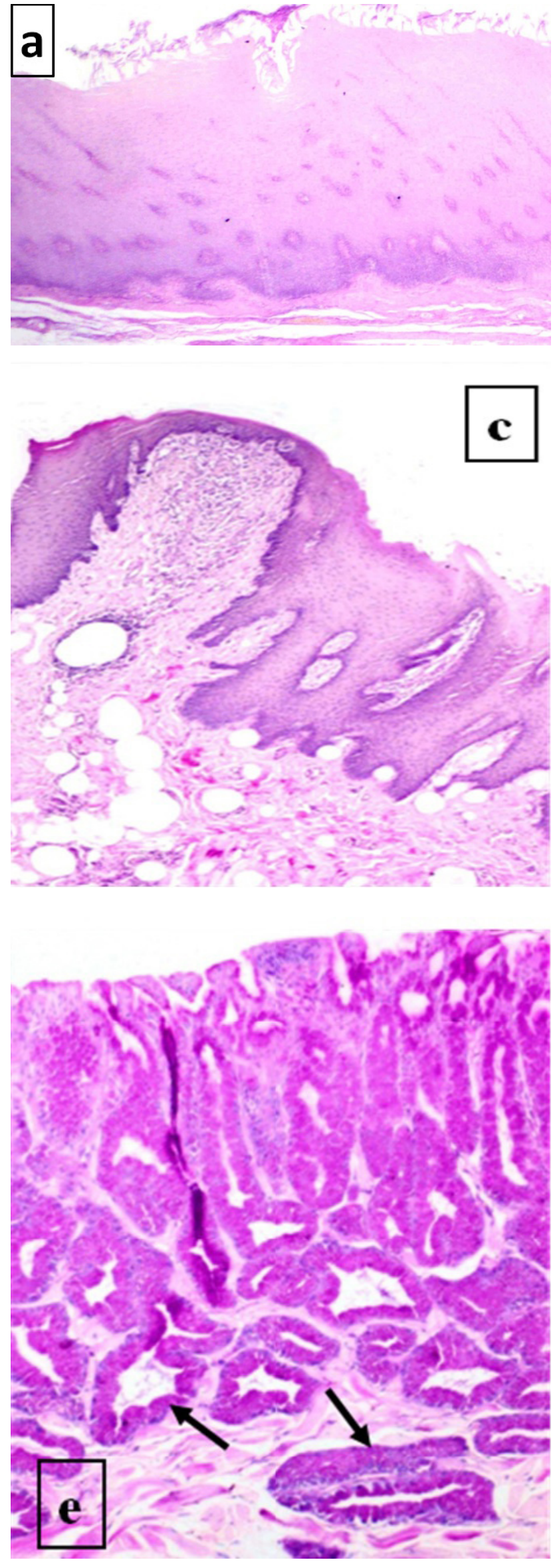
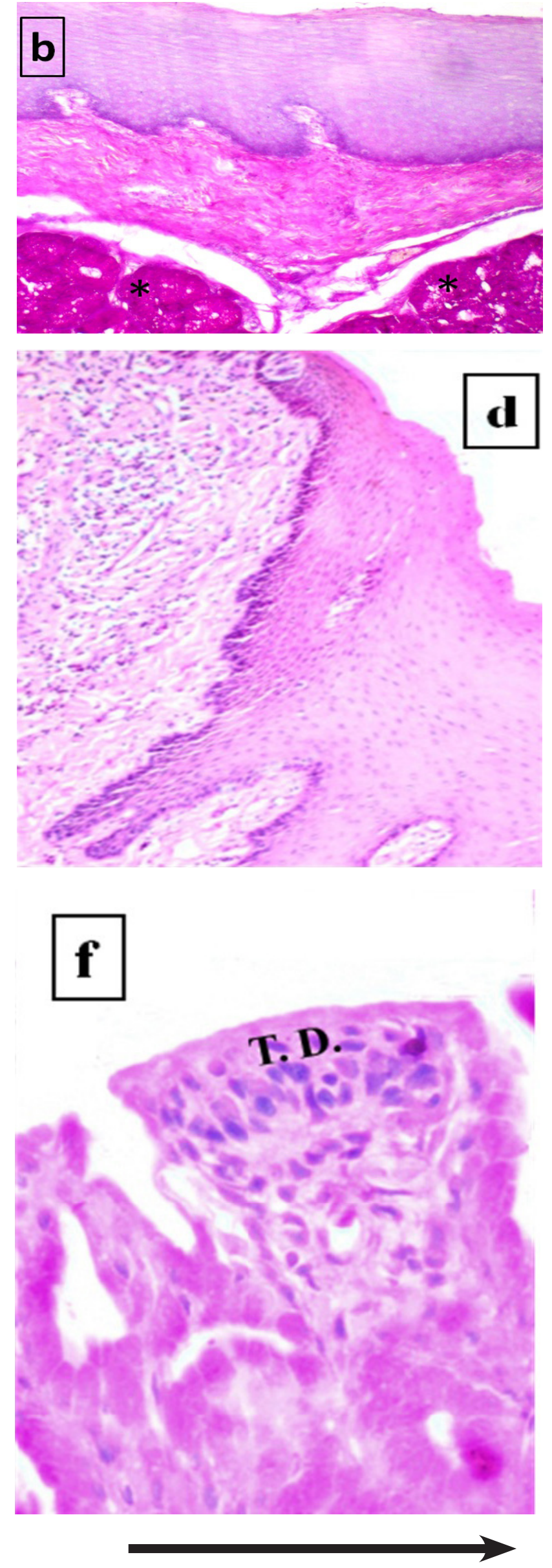

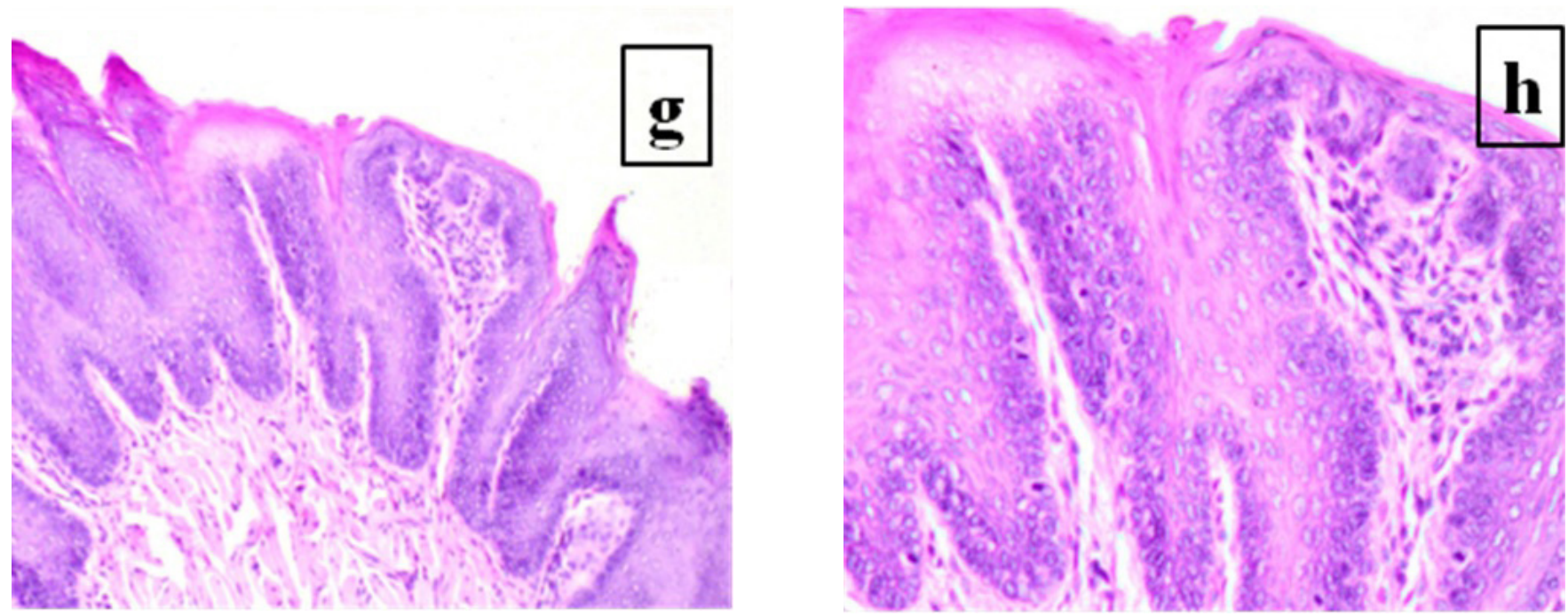

Fig. 14: Photomicrographs showing the species reaction to PAS; (a) weak to moderate reaction of the chicken's tongue (PAS, Orig. Mag. 40) (b) with heavily stained lingual glands(asterisk) (PAS, Orig. Mag. 100). (c) Camel demonstrated weak to moderate +ve staining (PAS, Orig. Mag. 40), (d) higher magnification (PAS, Orig. Mag. 100). (e) Strong staining intensity of the frog's lingual glands(arrows) (PAS, Orig Mag. 100), (f) strongly stained TD cells (PAS, Orig. Mag. 400). (g) Moderate reaction of the rabbit (PAS, Orig. Mag. 100),

(h) higher magnification (PAS, Orig. Mag. 200).
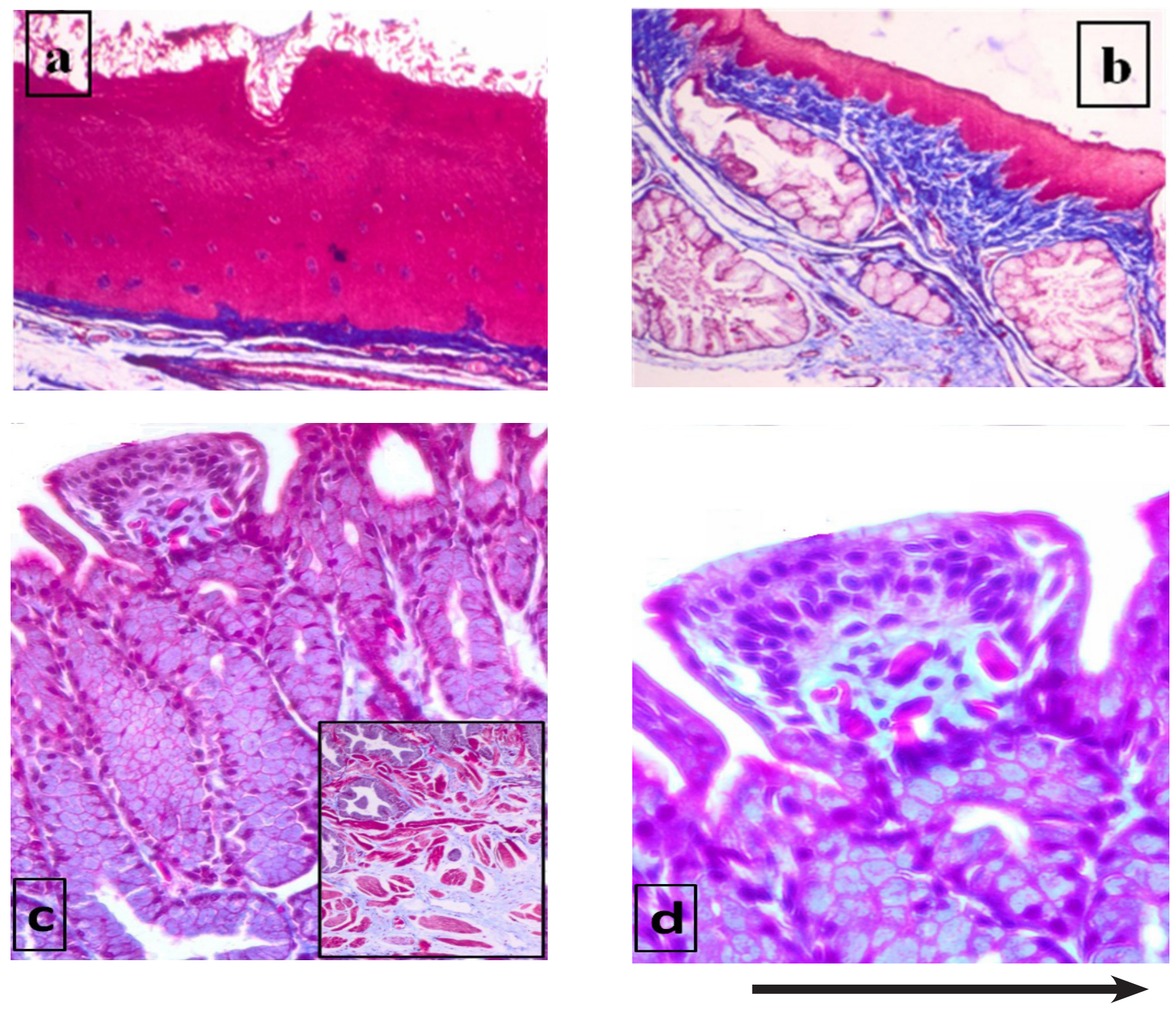

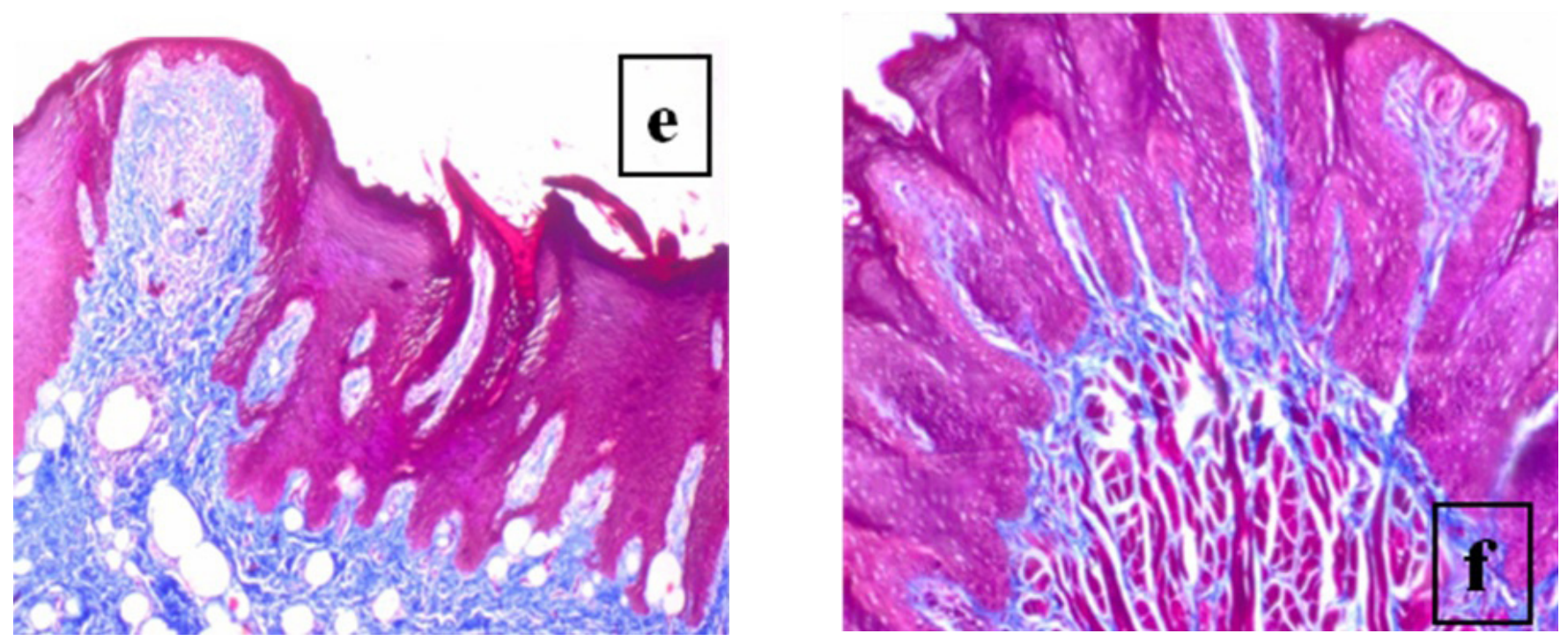

Fig. 15: Photomicrographs showing the species reaction to Masson's Trichrome; (a) the chicken's tongue showed densely packed collagen fibers anteriorly, (b) a network configuration posteriorly (a,b; Masson's Trichrome, Orig. Mag. 40). (c) Frog's tongue displayed less staining intensity (Masson's Trichrome, Orig. Mag. 200), Inset: muscle fibersa mong faintly stained fibers (Masson's Trichrome, Orig. Mag. 100), (d) higher magnification (Masson's Trichrome, Orig. Mag. 400). (e) Moderate staining intensity of camel (Masson's Trichrome, Orig. Mag. 40). (f) Rabbit with moderate stained fibers in lamina propria between lingual muscles (Masson's Trichrome, Orig. Mag. 100).
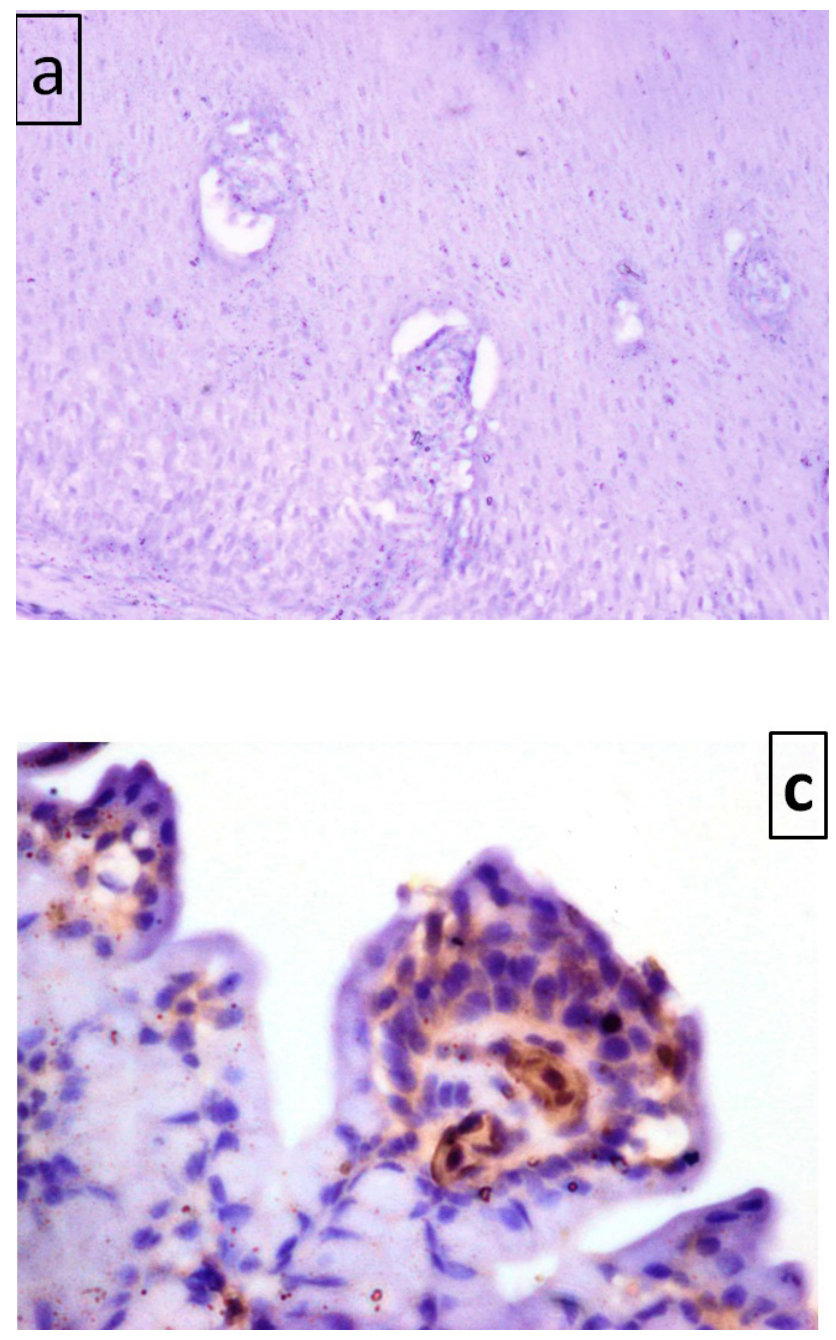

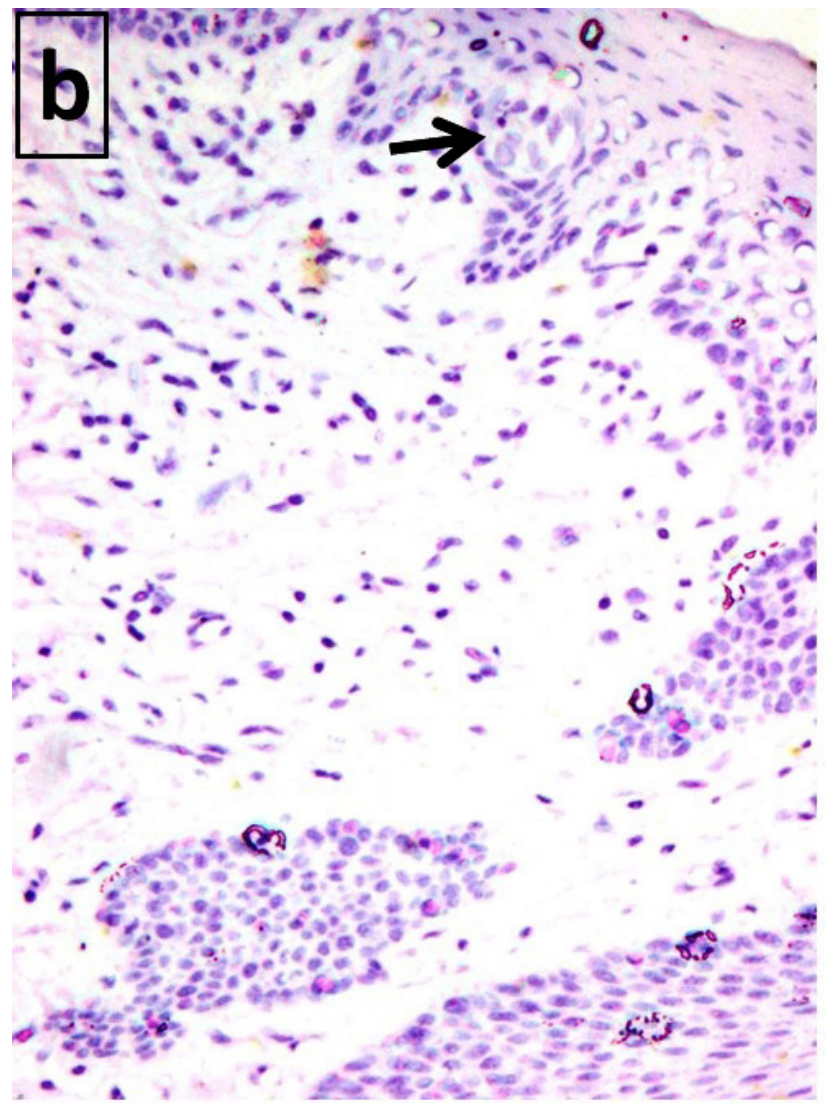



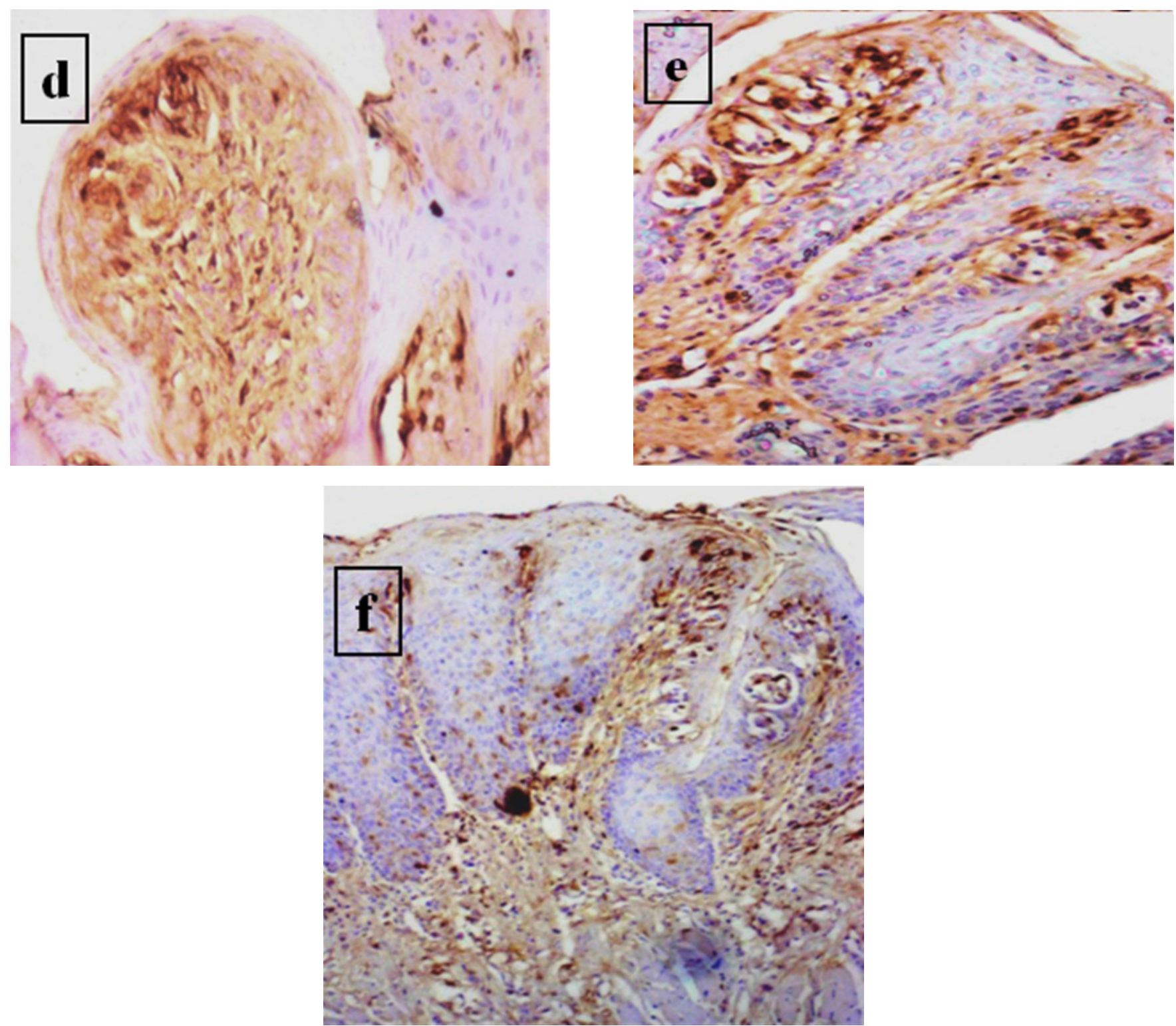

Fig. 16: Photomicrographs showing species reaction to anti-mGluR4; (a) Chicken (anti-mGluR4, Orig. Mag. 200). (b) Camel revealed negative reaction in taste bud (arrow) (anti-mGluR4, Orig. Mag. 200). (c) Moderate reactivity among the cells of the frog's TD (anti-mGluR4, Orig. Mag. 400). (d) Fungiform papillae of rabbit displayed moderate immune reaction (anti-mGluR4, Orig. Mag. 200), (e) foliate strongest reactivity (anti-mGluR4, Orig. Mag. 200), (f) circumvallate with least reaction (anti-mGluR4, Orig. Mag. 200).

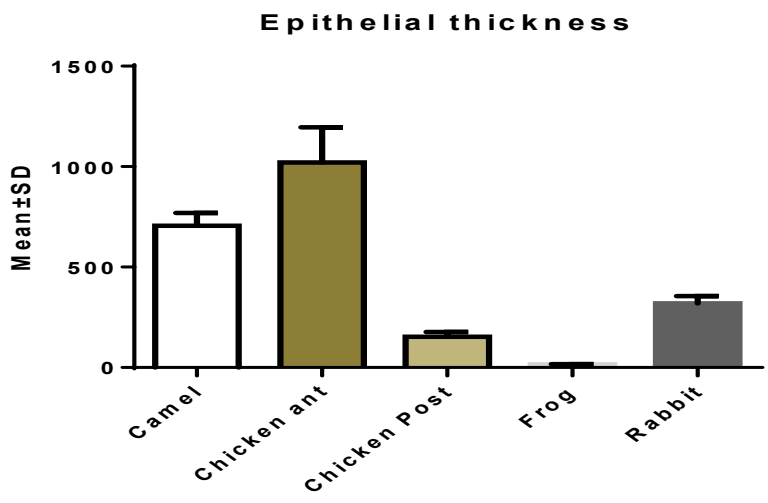

Fig. 17: Bar chart showing mean $\pm \mathrm{SD}$ of epithelial thickness among different species.

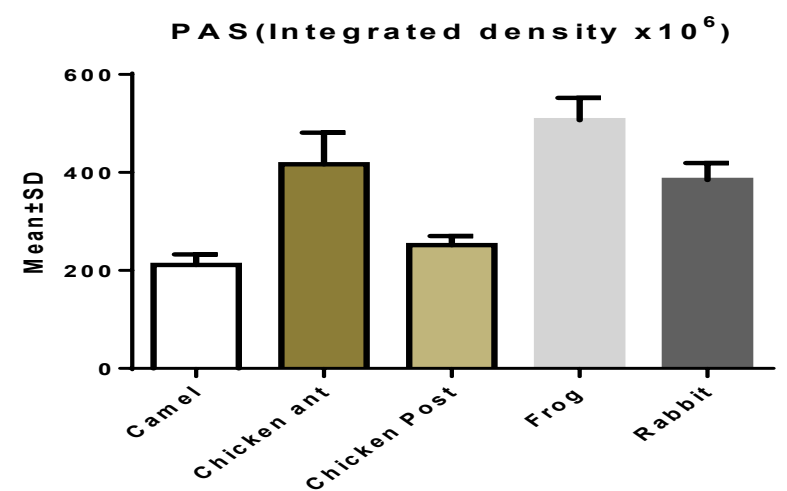

Fig. 18: Bar chart showing mean \pm SD of PAS (Integrated density X106) among different species. 


\section{Masson trichrome(ID $\left.\times 10^{5}\right)$}

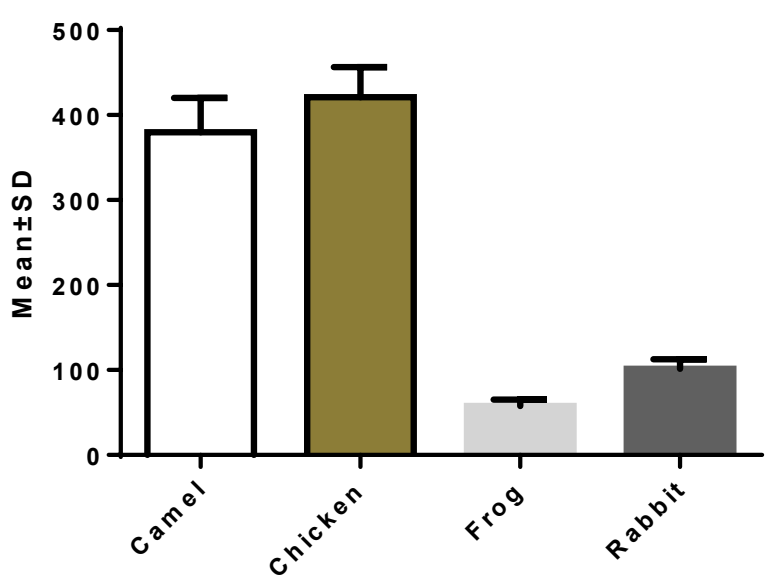

Fig. 19: Bar chart showing mean $\pm \mathrm{SD}$ of Masson trichrome (Integrated density $\mathrm{X} 10^{5}$ ) among different species.
Im m uno-anti m G lu R 4

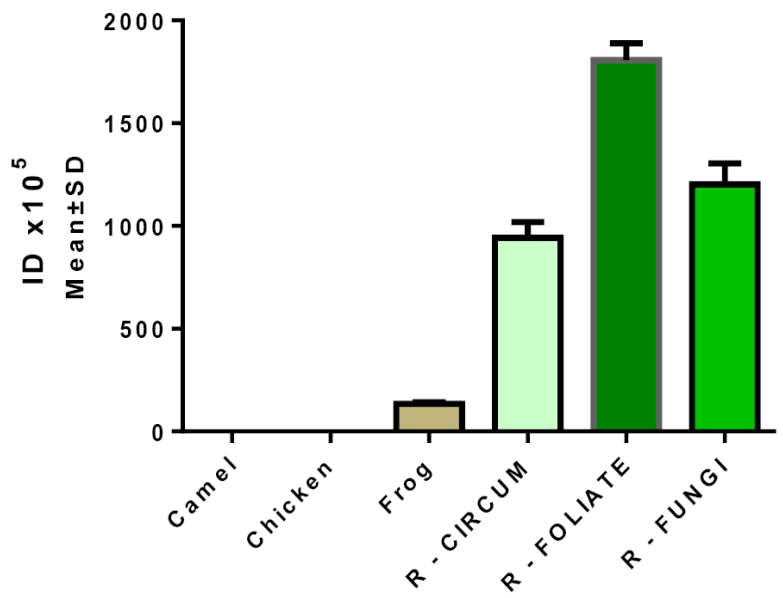

Fig. 20: Bar chart showing mean $\pm \mathrm{SD}$ of anti mGluR4- intensity (Integrated density $\mathrm{X} 10^{5}$ ) among different species.

Table I: Showing epithelial thickness among the four studied species

\begin{tabular}{|c|c|c|c|c|c|}
\hline & Camel & Chicken ant & Chicken Post & Frog & Rabbit \\
\hline Mean \pm SD & $705.8 \pm 63.63$ & $1021 \pm 174.8$ & $153.0 \pm 23.66$ & $15.63 \pm 1.413$ & $319.4 \pm 36.56$ \\
\hline \multirow[t]{4}{*}{ Posthoc } & & $\mathrm{P} 1=<0.001^{*}$ & $\mathrm{P} 1=<0.001^{*}$ & $\mathrm{P} 1=<0.001^{*}$ & $\mathrm{P} 1=<0.001^{*}$ \\
\hline & & & $\mathrm{P} 2=<0.001^{*}$ & $\mathrm{P} 2=<0.001^{*}$ & $\mathrm{P} 2=<0.001^{*}$ \\
\hline & & & & $\mathrm{P} 3=0.007^{*}$ & $\mathrm{P} 3=<0.001^{*}$ \\
\hline & & & & & $\mathrm{P} 4=<0.001^{*}$ \\
\hline
\end{tabular}

Data expressed either as mean \pm SD

SD:standard deviation P:Probability *:significance $<0.05$

Test used: One way ANOVA followed by post-hoc tukey

P1: significance relative to Camel Group

P2: significance relative to Chicken ant Group

P3: significance relative to Chicken Post Group

P4: significance relative to Frog Group

Table II: Showing PAS staining intensity (Integrated density X106) among the four studied species

\begin{tabular}{|c|c|c|c|c|c|}
\hline & Camel & Chicken ant & Chicken Post & Frog & Rabbit \\
\hline ID $x 10^{6}$ Mean \pm SD & $211.2 \pm 21.35$ & $417.0 \pm 64.37$ & $251.6 \pm 18.49$ & $506.9 \pm 45.17$ & $384.5 \pm 34.84$ \\
\hline \multirow[t]{4}{*}{ Posthoc } & & $\mathrm{P} 1=<0.001^{*}$ & $\mathrm{P} 1=0.18$ & $\mathrm{P} 1=<0.001^{*}$ & $\mathrm{P} 1=<0.001^{*}$ \\
\hline & & & $\mathrm{P} 2=<0.001^{*}$ & $\mathrm{P} 2=<0.001^{*}$ & $\mathrm{P} 2=0.39$ \\
\hline & & & & $\mathrm{P} 3=<0.001^{*}$ & $\mathrm{P} 3=<0.001^{*}$ \\
\hline & & & & & $\mathrm{P} 4=<0.001^{*}$ \\
\hline
\end{tabular}

Data expressed either as mean \pm SD

SD:standard deviation P:Probability *:significance $<0.05$

Test used: One way ANOVA followed by post-hoc tukey

P1: significance relative to Camel Group

P2: significance relative to Chicken ant Group

P3: significance relative to Chicken Post Group

P4: significance relative to Frog Group 
Table III: Showing Masson trichrome staining intensity (Integrated Density X10 $0^{5}$ ) among the four studied species

\begin{tabular}{lcccc}
\hline & Camel & Chicken & Frog & Rabbit \\
\hline ID x $10^{5}$ Mean \pm SD & $379.9 \pm 40.08$ & $421.1 \pm 35.57$ & $57.65 \pm 7.488$ & $101.6 \pm 11.18$ \\
Posthoc & & $P 1=0.01^{*}$ & $P 1=<0.001^{*}$ & $P 2=<0.001^{*}$ \\
& & & $P 2=<0.001^{*}$ & $P 3=0.0057^{*}$ \\
\hline
\end{tabular}

Data expressed either as mean \pm SD

SD:standard deviation P:Probability *:significance $<0.05$

Test used: One way ANOVA followed by post-hoc tukey

P1: significance relative to Camel Group

P2: significance relative to Chicken Group

P3: significance relative to Frog Group

Table IV: Showing Immuno-anti mGluR4- intensity (Integrated density $\mathrm{X} 10^{5}$ ) among the four studied species

\begin{tabular}{|c|c|c|c|c|c|c|}
\hline & Camel & Chicken & Frog & R - CIRCUM & R - FOLIATE & R - FUNGI \\
\hline ID $\times 10^{5}$ Mean \pm SD & $0.0 \pm 0.0$ & $0.0 \pm 0.0$ & $134.4 \pm 7.463$ & $942.2 \pm 76.72$ & $1808 \pm 81.02$ & $1203 \pm 101.5$ \\
\hline \multirow[t]{5}{*}{ Posthoc } & & & $\mathrm{P} 1=<0.001^{*}$ & $\mathrm{P} 1=<0.001^{*}$ & $\mathrm{P} 1=<0.001^{*}$ & $\mathrm{P} 1=<0.001^{*}$ \\
\hline & & & $\mathrm{P} 2=<0.001^{*}$ & $\mathrm{P} 2=<0.001^{*}$ & $\mathrm{P} 2=<0.001^{*}$ & $\mathrm{P} 2=<0.001^{*}$ \\
\hline & & & & $\mathrm{P} 3=<0.001^{*}$ & $\mathrm{P} 3=<0.001^{*}$ & $\mathrm{P} 3=<0.001^{*}$ \\
\hline & & & & & $\mathrm{P} 4=<0.001^{*}$ & $\mathrm{P} 4=<0.001^{*}$ \\
\hline & & & & & & $\mathrm{P} 5=<0.001^{*}$ \\
\hline
\end{tabular}

Data expressed either as mean \pm SD

SD:standard deviation P:Probability *:significance $<0.05$

Test used: One way ANOVA followed by post-hoc tukey

P1: significance relative to Camel Group

P2: significance relative to Chicken Group

P3: significance relative to Frog Group

P4:significance relative to R - CIRCUM Group

P5: significance relative to R - FOLIATE Group

\section{DISCUSSION}

Dietary characteristics in different animal species possibly affect the morphology of the digestive organs including tongue and its papillae. Therefore, previous comparative studies have illustrated diverse morphology and histology of the lingual papillae in different species $^{[19]}$. In the present study, different animal orders having different feeding habits were selected to ascertain the association of the histological structure of dorsal lingual surface with these habits. The histological and histochemical differences of the dorsal lingual mucosa including gustatory papillae were detected in four different animal species. Besides, immunohistochemical assessment of the umami mGluR4 was done to estimate the existence of umami taste potentiality in these species.

The H\&E sections of the chicken tongue dorsum revealed obvious thick stratified keratinized epithelium in both apex and body that could be ascribed to its involvement in food manipulation as well as adequate mechanical protection ${ }^{[20]}$. Also, the observed microridges were thought to function in mucus adhesion to tongue's epithelial surface ${ }^{[9]}$. Moreover, the existence of numerous intraepithelial taste buds was confirmed by some authors who stated that $2 \%$ of taste buds were detected in the chicken tongue posteriorly and $29 \%$ in the anterior region. Taste buds were mentioned to be either solitary taste buds lie singly or in groups close to the surface or glandular buds which were associated with the salivary glands ducts ${ }^{[21]}$. In tongue body and root, the secretion of the lingual glands plays an important function in lubrication, thus facilitates food ingestion and swallowing. This is necessary since birds lack teeth and unable to masticate food adequately. The glandular secretion also glues seeds or insects into a sticky ball for easy swallowing. In addition, the secreted mucin exerts a protective effect against the acidic enzymatic factors as well as microorganisms ${ }^{[20,22]}$. For the noted lymphocyes aggregates, Udensi et al. ${ }^{[20]}$ reported that these aggregates play a fundamental role in the immune responses. The observed hyaline cartilage was thought to form the paraglossum of birds' tongues to provide firmness and to act as a skeletal element for muscle attachment ${ }^{[9,20]}$.

In parallel to other investigations ${ }^{[23]}$, the $H \& E$ frog sections presented the filiform and fungiform papillary walls composed of mucous secreting monolayer columnar epithelium with no goblet cells. A discontinuous layer of spindle-shaped cells was also seen just beneath the basement membrane. Other authors described this layer 
as the stratum germinativum for its overlying layer and considered it as a connective tissue element ${ }^{[24]}$. The large scattered fungiform papillae among filiform were described as chemoreceptors ${ }^{[25]}$. The gustatory discs in ongoing study were constituted of pluristratified epithelium with an apical layer of mucous cells. In accordance, it was revealed that the frog TD epithelium consisted of different types of epithelial cells ${ }^{[23]}$. Ultrasructurally, upper apical layer was reported to be formed of mucous and wing cells which provide mechanical and metabolic support. The thickness of the TD undergoes seasonal variation as it is reduced during winter particularly its intermediate layer. The unusual organization of the frog TDs attributed to its developed osmoreceptive system comparing to mammals to suite the aquatic environment ${ }^{[26]}$. The underlying tissue to the frog's epithelium was believed to be important for the tongue adhesive performance through coping with the exerted forces during tongue retraction and protraction ${ }^{[11]}$. The lingual glands prescribed in our sections were reported to secrete sticky protein-rich material for pray grasp ${ }^{[23]}$. Moreover, the LP was attached to a network of striated muscles. In accordance, Kleinteich and Gorb ${ }^{[25]}$ described the tongue muscles in frog to be built from protracting and retracting muscles with tightly interwoven muscle fibers contributing to the equal force distribution to provide high pulling forces.

Camels and rabbits presented nearly similar morphological and histological features of their tongues. Camels are acclimatized to feed on thorny plants; that was directly reflected in their tongues' results ${ }^{[27,28]}$. In the current study, only fungiform and circumvallate papillae were detected in camels, while the three gustatory papillae including foliate papillae were observed in rabbits. Some reports $^{[6,29-31]}$ displayed parallel results in camels that exhibited a huge size of lingual papillae dissimilar to some vertebrates including rabbits ${ }^{[32]}$. Concurrently, others ${ }^{[33,34]}$ proposed that the broad top of fungiform papillae designated to increase the surface areas and serve for the sensory taste organs. Also, the observed thick keratinized epithelium covering the fungiform papillae might be attributed to the need for mucosal protection against stiff dried nutrients and thus enhanced the efficiency in low quality forages digestion by camels $^{[35]}$. Similarly, the keratinized epithelium in rabbits protects the papillae against strong mechanical stresses caused by rigid food ${ }^{[36]}$. Our H\&E sections declared few taste buds in camels, but in rabbits one or two were detected. However, in most cases two to five taste buds were found on the rabbit's fungiform papilla. On contrary, some authors ${ }^{[13,37,38]}$ assessed the lack of taste buds in the fungiform papillae of Egyptian camels which maybe a deceptive finding due to non-representing tissue materials usage ${ }^{[6]}$.

Like previous reports ${ }^{[1,3]}$, the vallate papillae of both animals in this work were surrounded by wide deep trough that enhance food accessibility to taste buds. It was illustrated that plenty, asymmetrical gigantic vallate papillae were found in camels comparing to the two smaller papillae detected in rabbits. Furthermore, these papillae were believed to exhibit characteristic organization in camilidae to compensate the absence of foliate papillae ${ }^{[35]}$ Some papillae displayed microridges that keep prolonged contact of saliva to the taste buds ${ }^{[39]}$. In this work, foliate papillae of rabbits were covered with non-keratinized epithelium which simulated the results of AL-Mahmodi ${ }^{[3]}$. Yet, Assem et al. ${ }^{[26]}$ ascribed the apparent detachment of the most superficial cell layer of these papillae to the higher rate frictional desquamation of epithelial covering. Researches described this epithelium as para-keratinized and attributed this to food nature, as if the rabbits feed on hard dry diet, the epithelial lining would change into keratinized as a functional adaptation ${ }^{[32]}$. Moreover, epithelial streaks identified in our specimens may permit numerous blood vessels in the LP to extend into the CT core $^{[40]}$. The papillary cores displayed multiple secondary papillae which increase the mechanical anchorage as well as the blood and nerve supply ${ }^{[39]}$. It was elucidated that Von Ebner glands in camel were involved in furrow washing effect ${ }^{[6]}$ whereas those associated with rabbit were elucidated to play a role in taste perception ${ }^{[39]}$.

In terms of epithelial thickness in the four different species of this study, we statistically illustrated significant variations among species. In a descending manner, we found that anterior lingual epithelium of chicken exhibited the greatest thickness $>$ camels' specimens $>$ rabbits specimens $>$ posterior lingual epithelium of chicken $>$ frogs' specimens. In harmony to our results, it was elucidated that the epithelial thickness and epithelial ridges are more or less proportional to the size of the animal species $^{[17]}$. Although there were slight variations in the anterior lingual epithelium of chicken in this study so that they have the thickest epithelium among species. On the other side, herein it was clearly evident that the lingual epithelial ridges in chicken appeared more or less flat comparing to the largest ones of camels followed by those of rabbits in descending manner.

To enhance the previous H\&E epithelial results, we analyzed the histochemical reaction of the dorsal lingual epithelium to PAS for its affinity in staining glycogen and mucin in epithelial cells which in turn may aid in discriminating keratinized from non keratinized epithelium. Our statistical results revealed that the greatest PAS staining intensity per surface area was in the frog $>$ anterior lingual epithelium of chicken $>$ rabbits' specimens $>$ posterior lingual epithelium of chicken $>$ camels' specimens. Likewise, insignificant differences were noted between rabbit and chicken anterior lingual epithelium as well as between camel and chicken posterior lingual epithelium. According to Reddy et al. ${ }^{[1]}$ study, all specimens contained varying amounts of intracellular glycogen aggregates proportional to the degree of PAS staining. Moreover, it was illustrated that keratinized epithelium contained small amount of glycogen compared to the non keratinized mucosa, so that it appeared that the glycogen and keratinization are inversely related ${ }^{[17]}$. On 
the other side, the intense PAS positive epithelial surface in frog was not related to keratinization ${ }^{[16]}$, but to the acid mucopolysaccharides secreted by the mucous secreting cells of filiform papillae and by those forming the top of fungiform $\mathrm{TD}^{[26,42,43]}$.

On the other hand, Masson's trichrome stain showed different collagen fibrous distribution and staining intensity in the LP of the studied species particularly that collagen fibers are the major constituent of LP. Collagen fibers stained deep blue in chicken's tongue specimens, while apparent mild affinity was detected in the frog's tongue. Camel and rabbit specimens revealed apparent moderate staining of the collagen fibers with similar distribution of collagen fibers. Thus, histochemical and statistical Masson's trichrome results elucidated that density of collagen fibers in lamina propria was more pronounced in chicken $>$ camels $>$ rabbits $>$ frogs with significant differences among all species. The apparent intensity of Masson trichrome staining was supposed to reflect the degree of bundling of collagen so that it may be greatest in chicken and least in frog ${ }^{[17,44]}$.

It was elucidated that taste is the most significant sense in determining food selection and palatability ${ }^{[35,45]}$ and also for chicken is directly related to the effectiveness of poultry farming ${ }^{[45]}$. Taste sensation commences by gustatory papillae that were histologically studied in this work. Information acquirement regarding the umami taste perception and receptors is very important to aid in controlling animals and their gut health specially the domestic animals ${ }^{[35,45]}$. Accordingly, we studied the immuno-histochemical localization of taste mGluR4 as a umami receptor in the taste cells of the lingual gustatory papillae in different animal species. We revealed negative immune reaction to mGluR4 in the chicken and camel. This result could be related to the fact that the used antibody is not specific to either chicken or camel mGluR4. Fewer genes for taste receptors were observed in chicken comparing to mammals thus the lower chicken taste acuity was detected ${ }^{[21]}$. Though it was established that chicken strongly respond to umami tastants, yet the low detected number of lingual taste buds reflected that the tongue doesn't play a primary role in taste function. Likewise, The T1R1 and T1R3 heterodimer umami receptors were illustrated in chicken tongue ${ }^{[45,46]}$ whilst the taste-mGluR4 was expressed in chicken gut ${ }^{[45]}$. For camels; it was reported that umami taste is closely related to savory and earthy taste. Also, geosmin (2-methylisoborneol) was believed to be responsible for unpleasant tastes in water and provides a characteristic earthy flavor. Camels can sense the smell of geosmin in wet soil; thus can track it to find an oasis. Accordingly, we supposed that camels most probably possess taste receptors for earthy taste (umami). Thus, the detected negativity to mGluR4 in camel was probably attributed to the fact that the used antibody was not specific to camel's mGluR $4^{[8,47-50]}$.

On the other hand, moderate immune reactivity was evident in the frog's TDs. Concurrently, amphibian studies illustrated that their taste system revealed certain amino acids known to be detected by umami receptors. Frogs possess numerous V2R receptor genes and receptor sensor channels that might be responsible for amino acids detection and depolarization of type II sensory taste cells respectively. Taste mGluR4 receptor was assisted to be negatively coupled to the cAMP cascade ${ }^{[8,43,51]}$. In frogs, cAMP was found to inactivate $\mathrm{K}+$ ion conductance through cAMP-regulated protein kinase $\mathrm{A}$ and thus caused membrane depolarization of taste cells ${ }^{[52]}$ in response to glutamate analogues ${ }^{[53]}$. Finally, the rabbit sections showed moderate to strong immunoreaction to mGluR4 in taste cells of gustatory papillae. Statistically, the strongest reaction to mGluR-4 in this study appeared in the rabbits papillae as follows foliate papillary gustatory system $>$ fungiform papillae $>$ circumvallate papillary gustatory system. In accordance, several studies showed that mGluR4 were immunized and purified from rabbits to be used in the immunohistochemical assays ${ }^{[8,54]}$. In addition, some investigators mentioned that rabbits showed a well developed lingual gustatory system and the survival of herbivores like rabbits depends on nutrient consumption and taste thus guiding the animals for the safe food choices. Umami tastants such as amino acids were also consumed by herbivore ${ }^{[55,56]}$. Significant variations in the immune anti-mGluR4 intensity among the different rabbit papillae were revealed and also between rabbits and frogs gustatory systems.

Finally, we summarized that chicken exhibited no papillation with intraepithelial taste buds, whereas only two types of papillae with mucous secreting function were displayed in frogs in addition to the largest taste disc among the studied species. On the other hand, camels and rabbits presented conventional papillary taste buds with huge papillary size and absence of foliate papillae in camels. Regarding umami mGluR4 reactivity, it was negative in chicken and camel but positive in frogs and rabbits with the strongest reaction in rabbits. Therefore, we concluded the direct association between morphological and histological variations of the masticatory lingual surface to the environmental factors that greatly contribute to dietary specialization and to other daily tongue uses, which in turn reflects the adaptation capability of the lingual tissue to diverse environmental changes.

In accordance to the forgoing studied animal species, we recommended the rabbit to be maintained as the most appropriate animal model for wide range of research applications because of its ease handling and close similarity of their oral tissues to those of human. On the other hand, the huge sized oral structures of the large camel models together with the diverse histological and functional variations of the small sized tissues in chicken and frog made samples collection and study in routine histological fields hard and inconsistent. Yet, these species could be convenient for further comparative studies involving various oral tissues. 


\section{ABBREVIATIONS}

H\&E: Hematoxylin and Eosin, PAS: Periodic acid- Schiff stain, PBS: Phosphate-buffered saline, mGluR4: Metabotropic glutamate receptor 4, DAB: Diaminobenzidine, LP: Lamina propria, TD: Taste disc, CT: Connective tissue.

\section{CONFLICTS OF INTERESTS}

There are no conflicts of interests.

\section{REFERENCES}

1. Sakr SMI, Taki-El-Deen FMA and Aboelwafa HR: Comparative light and scanning electron microscopic study of the lingual papillae in three different mammalian animals; Hemiechinus auritus (Erinaceomorpha: Erinaceidae), Cavia porcellus (Rodentia: Caviidae) and Mustela nivalis vulgaris (Carnivora: Mustelidae). Life Sci. (2013) 10(4): 3082-3093.

2. Abumandour MMA: Morphological Comparison of the Filiform Papillae of New Zealand White Rabbits (Oryctolagus cuniculus) as Domestic Mammals and Egyptian Fruit Bat (Rousettus aegyptiacus) as Wild Mammals Using Scanning Electron Microscopic Specimens. Int. J. Morphol. (2014) 32(4):1407-1417.

3. AL-Mahmodi AMM: Anatomical and Histological study of the Tongue of wild adult male Rabbits (Oryctolagus cuniculus f. domestica) in AL-Najaf province. Kufa Journal for Veterinary Medical Sciences. (2016) 7(2): 79-94.

4. Abd AL-Rhman SA, AL-Fartwsy AR and AL-Shuaily EH: Morphohistological study of the tongue in local mice species by using special stain. Journal of American Science. (2016) 12(8): 13-20.

5. Fulse AC, Mishra P, Ksheersagar DD and Paikrao VM: Comparative morphology and histology of buffalo and goat tongue with human tongue. Int J Exp Pharm. (2015) 5(2): 70-77.

6. Abou-Elhamd AS, Abd-Elkareem $\mathrm{M}$ and Zayed AEZ: Morphogenesis of lingual papillae of one-humped camel (Camelus dromedarius) during prenatal life: A light and scanning electron microscopic study. Anat. Histol. Embryol. (2018) 47(1): 38-45.

7. Nonaka K, Zheng JH and Kobayashi K: Comparative morphological study on the lingual papillae and their connective tissue cores in rabbits. Okajimas Folia. Anat. Jpn. (2008) 85(2): 57-66.

8. Chaudhari N, Pereira E and Roper SD: Taste receptors for umami: the case for multiple receptors. Am. J. Clin. Nutr. (2009) 90(3):738S-742S.

9. Erdogan $\mathrm{S}$ and Iwasakib $\mathrm{S}$ : Function-related morphological characteristics and specialized structures of the avian tongue. Ann Anat. (2014) 196(2-3):75-87.
10. Cheled-Shoval SL, Druyan S and Uni Z: Bitter, sweet and umami taste receptors and downstream signaling effectors: Expression in embryonic and growing chicken gastrointestinal tract. Poult Sci. (2015) 94(8): 1928-1941.

11. Kleinteich $\mathrm{T}$ and Gorb $\mathrm{SN}$ : Frog tongue surface microstructures: functional and evolutionary patterns. Beilstein J. Nanotechnol. (2016) 7: 893-903.

12. Mnati EM, Mutlak BH and Al-Jumaily IS: Morphological and histological description of the tongue in the frog rana ridibunda. Diyala journal for pure science; (2014) 10(3): 1-11.

13. Mohammed, G.A.: Ultramorphological studies on the lingual papillae of Rabbit (Oryctolagus cuniculus) in relation to its feeding habits. Proc. 7th Int. Con. Biol. Sci., 7: 6- 10, 2012.

14. Böhmer E: Classification and Anatomical Characteristics of the Lagomorphs and Rodents. Ch. 2, Dentistry in Rabbits and Rodents. 1st ed., John Wiley \& Sons, Ltd. (2015) pp: 21-34.

15. Igwebuike U M, Ugwuoke W I and Udoumoh AF: Histological features of the tongue of the common pigeon. Animal Research International. (2013) 10(3): 1779-1785.

16. Shoeib MB, Rizk AZ and Hassanin, AM: Comparative Morphological Studies on Lyssa in Carnivores and Camels with Special Reference to Its Surgical Resection. Journal of Advanced Veterinary Research. (2014) 4(3):135-141.

17. Delalande CT, Gervais F, Fisch C, Cuinea J, Bodo VB, Moingeon $\mathrm{P}$ and Mascarell L: Comparative analysis of the oral mucosae from rodents and non-rodents: Application to the nonclinical evaluation of sublingual immunotherapy products. PLoS ONE, (2017) 12(9): e0183398.

18. Wang S, Wei X, Chen B, Zhao M, Song G, Zhang $\mathrm{Z}$ and $\mathrm{Li} \mathrm{N}$ : Expression of metabotropic glutamate receptor 4 in osteosarcoma. Mol Clin Oncol. (2016) 4 (1): 65-69.

19. Yoshimura K, Ono K, Shindo J, Iwasaki SI and Kageyama I: Comparative morphology of the lingual papillae and their connective tissue cores in the tongue of the Abyssinian black-and-white colobus (Colobus guereza). Anat Sci Int. (2019) 94(3):225-237.

20. Udensi MI, Wilfred IU and Anietie FU: Histological features of the tongue of the common pigeon (Columba livia). Animal Research International. (2013) 10(3): 1779-1785.

21. Rajapaksha P, Wang Z, Venkatesan N, Tehrani KF, Payne J, Swetenburg RL, Kawabata F: Labeling and analysis of chicken taste buds using molecular markers in oral epithelial sheets. Sci Rep. (2016) Nov. 6: 37247. 
22. Al-Nefeiy FA and Alahmary BA:Morphological, histological and histochemical studies of the lingual salivary glands of the rock dove, Patagioenas livia (Columbidae). Int.J.Curr.Res.Aca.Rev. 3(8): 280-289.

23. Lőw $\mathrm{P}$, Molnár $\mathrm{K}$ and Kriska $\mathrm{G}$ : Atlas of Animal Anatomy and Histology. Part II. (2016) p: 225, Springer International Publishing;. DOI 10.1007/978-3-319-25172-1.

24. Iwasaki $\mathrm{S}$ and Wanichanon $\mathrm{C}$ : Fine structure of the dorsal lingual epithelium of the frog, rana rugosa. Tissue Cell. (1991) 23(3): 385-391.

25. Kleinteich $\mathrm{T}$ and Gorb $\mathrm{SN}$ : Frog tongue acts as muscle-powered adhesive tape. R Soc open sci. (2015) Sep. 2(9): 150333.

26. Osculati F and Sbarbati A: The frog taste disc: a prototype of the vertebrate gustatory organ. Prog Neurobiol. (1995) 46(4): 351-399.

27. Iwasaki $\mathrm{S}$ and Kobayashi K: Scanning and Transmission Electron Microscopical Studies on the Lingual Dorsal Epithelium of Chickens. Acta Anat Nippon. (1986) 61(2): 83-96.

28. Bello A, Alimi OO, Sonfada ML, Umaru MA, Onu JE, Onyeanusi BI and Shehu SA: Histomorphometric Study of the Prenatal Development of the Circumvallate Papillae of One-Humped Camel (Camelus Dromedarius). Anat Physiol. (2015) 5(1): 1-5.

29. Eerdunchaolu Takehana K, Yamamoto E, Kobayashi A, Cao G, Baiyin Ueda $\mathrm{H}$ and Tangkawattana P: Characteristics of dorsal lingual papillae of the Bactrian camel (Camelus bactrianus). Anat Histol Embryol. (2001) 30(3):147-51.

30. Salehi E, Pousti I, Gilanpoor H, and Adibmoradi M: The morphological observations of some lingual papillae in camelus dromedaries embryoes. Journal of Animal and Veterinary Advances. (2010) 9:514-518.

31. Dyce KM, Sack WO and Wensing CJG: Textbook of Veterinary Anatomy, 2nd ed., WB Saunders, Philadelphia, Pennsylvania. (1996) pp: 856.

32. Assem MMM, Ahmed MA, Shawkat SM and Zaatar HS: Comparative histological, immunohistochemical and scanning electron microscopic study of the foliate papillae in different experimental animals. Cairo Dental Journal. (2014) 1(30): 1-15.

33. Kulawik $\mathrm{M}$ and Godynicki S: Fungiform papillae of the tongue in the rabbit (Oryctolagus cuniculus). Pol J Vet Sci. (2007) 10(1): 25-7.

34. Ojima K, Takahashi T, Matsumoto S, Takeda M, Saiki $\mathrm{C}$ and Mitsuhashi F: Angioarchitectural structure of the fungiform papillae on rabbit tongue anterodorsal surface. Annals of Anatomy - Anatomischer Anzeiger. (1997) 179(4): 329-333.
35. Erdogan S, ARIAS S and Perez W: Morphofunctional Structure of the Lingual Papillae in Three Species of South American Camelids: Alpaca, Guanaco, and Llama. Microscopy research and technique. 2016.

36. Mahmoud M, Abd-Elnaeim M, Zayed AE and Leiser, R.: Morphological characteristics of the tongue and its papillae in the donkey (Equusasinus): a light and scanning electron microscopical study. Ann Anat. (2002) 184(5): 473-480.

37. Barone R: Anatomie comparée des mammifères domestiques: ostéologie. Paris: Vigot. (1976) 75-329.

38. Korany NS and Bachir MH: Morphofunctional study of different tongue papillae in ruminants and rodentia. a) Scanning Electron Microscopic and histological studies. Cairo Dental J. (2004) 20(2): 215-220.

39. Elnasharty M, El Sharaby A, and Nor El-din A: Histogenesis of Rabbit Vallate Papillae. International Journal of Animal and Veterinary Sciences. (2013) 7(4): 261-268.

40. Kulawik M and Godynicki S: Foliate papillae on the tongue in the domestic rabbit (Oryctolagus Cuniculus F. Domestica). EJPAU. (2006) 9(3).

41. Reddy M, Kumar NG, Manyam R., Swetha P, Supriya AN and Bharath TS: Comparison of Glycogen Positive Cells in Oral Smears with Random Blood Sugar Levels of Type 2 Diabetes Patients. AMHSR. 2018 8(1): 1-5.

42. Orbo C, Gioglio L and Quacci D: The Paracoronal (Marginal) Cells of Fungiform Papilla of Rana esculenta. J. Electron Microsc. (1995) 44(4): 165-173.

43. Sato T, Nishishita K, Okada $\mathrm{Y}$ and Toda K: The Receptor Potential of Frog Taste Cells in Response to Cold and Warm Stimuli. Chem. Senses. (2010) 35(6): 491-499.

44. Reshma V, Varsha BK, Rakesh P, Radhika MB, Soumya $M$ and D'Mello S: Aggrandizing oral submucous fibrosis grading using an adjunct special stain: A pilot study. J Oral Maxillofac Pathol. (2016) 20(1): 36-46.

45. Yoshida Y, Kawabata Y, Kawabata F, Nishimura $\mathrm{S}$ and Tabata $\mathrm{S}$ : Expressions of multiple umami taste receptors in oral and gastrointestinal tissues, and umami taste synergism in chickens. Biochem Biophys Res Commun. (2015) 466(3): 346-349.

46. Liu HX, Rajapaksha P, Wang Z, Kramer NE and Marshall BJ: An Update on the Sense of Taste in Chickens: A Better Developed System that Previously Appreciated. J Nutr Food Sci. (2018) 8(2). pii: 686. doi: 10.4172/2155-9600.1000686.

47. Lu G, Edwards CG, Fellman JK, Mattinson DS, Navazio J: Biosynthetic origin of geosmin in red beets (Beta vulgaris L.). J Agric Food Chem. (2003) 51(4):1026-1029. 
48. Ploeg MV and Boyd CE: Cyanobacteria and geosmin. J World Aquaculture Soc. (2007) 22: 207-216.

49. Jüttner $F$ and Watson SB: Geosmin in source waters, review. Appl Env Microbiol. (2007) 73: 4395-4406.

50. Gerritsen VG: The earth's perfume. Protein Spotlight; June (2003) 35. Online at http://www.expasy.ch/spotlight/back_issues/035/.

51. Shi $\mathrm{P}$ and Zhang J: Contrasting modes of evolution between vertebrate sweet/umami receptor genes and bitter receptor genes. Mol Biol Evol. (2006) 23(2): 292-300.

52. Lindemann B: Chemoreception: Tasting the sweet and the bitter. Curr Biol. (1996) 6(10): 1234-1237.
53. Lin W and Kinnamon SC: Physiological evidence for ionotropic and metabotropic glutamate receptors in rat taste cells. J Neurophysiol. (1999) 82(5): 2061-2069.

54. Chaudhari1 N, Landin AM and Roper SD: A metabotropic glutamate receptor variant functions as a taste receptor. Nat neurosci. (2000) 3(2): 113-119.

55. Field KL, Bachmanov AA, Mennella JA, Beauchamp GK, Kimbal BA: Protein hydrolysates are avoided by herbivores but not by omnivores in two-choice preference tests. PLoS ONE. (2009) 4(1): e4126.

56. Bachmanov AA, Bosak NP, Lin C, Matsumoto I, Ohmoto M, Reed DR and Nelson TM: Genetics of Taste Receptors. Curr Pharm Des. (2014) 20(16): 2669-2683. 
الملخص العربى

\section{دراسة متلازمة نسيجية ولتذوق الأومامي بحليمات التذوق على الغثاء المخاطي الظهري في أنواع مختلفة من الحيوانات بلات

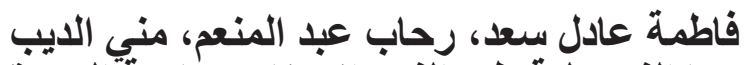

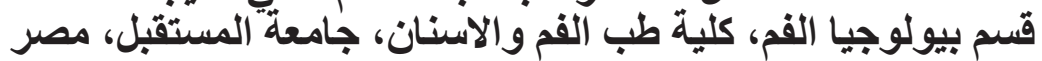

يعتبر التوصيف المقارن للغشاء المخاطي للفم لانواع حيوانات مختلفة ضروري لتصنيف أفضل النماذج الحيوانية التجريبية للبحث. الهدف من التجربة: تهدف التجربة الى مقارنة التركيب النسيجي للغشاء المخاطي الظهري ولحليمات التذوق باللسان وكذلك التفاعل الهيستوكيميائي المناعي لمستقبل تذوف أومامى معين لأنو اع مختلفة من الحيو انات. التجربة: تم الحصول على عينات من الاغشية المخاطية الظهرية للسان أربعة أنواع مختلفة من الحيو انات تشمل الدجاج و الضفادع و الأر انب و الجمال. وقد تم معالجتها للفحص النسيجي الروتيني ولصباغة النسيج هستوكيميائيا باستخدام صبغتي بيريوديك أسيد شيف و ماسون تر ايكروم بالاضافة الى تحديد التفاعل الهيستوكيميائى المناعى للجسم المضاد

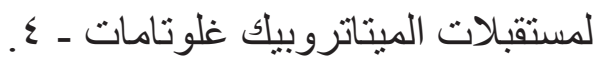
النتائج : أظهرت النتائج أن الغثاء المخاطي الظهري للسان كلا من الدجاج و الجمال و الأر انب لديه طبقية متقرنة مع تبين ان السمك الاكبر احصائيا وجد في الغشاء المخاطي الظهري الامامي للسان الدجاج. أما بالنسبة للضفادع فقد أظهرت النتائج أن الحليمات الخيطية و الحليمات الفطرية بالغشاء الظهري للسان أحادية الطبقة وتتكون من خلايا مفرزة للمخاط و طبقة خلايا مغز لية مجاورة. لوحظت فروق ليست ذات دلالة إحصائية في الصباغة الهستو كيميائية باستخدام بيريوديك أسبد شيف بين الغشاء المخاطي الظهري للسان كلا من الدجاج (فى الجزء الخلفي للسان) و الأر انب وكذلك بين الغشاء المخاطي الظهري لكلا من الدجاج (فى الجزء الخلفي للسان) و الإبل مع أكبر كثافة صبغية ملحوظة احصائيا وجدت في الضفادع و التي تعكس أعلى محتويات للجليكوجين و الميوسين. أما كثافة النسيج الضام ودرجة تحزم ألياف الكو لاجين التي أظهرتها نتائج صبغة الماسون نر اي كروم الهستوكيميائية كان بها اختلافًا كبيرًا بين أنو اع الحيو انات المختلفة حيث كانت الأعلى في الاجاج و الأقل في الضفادع. ولقد تم العثور على بر اعم التذوق داخل الغشاء المخاطي الظهري للسان الاجاج بينما أظهرت الضفادع أكبر جهاز تذوق بين الفقاريات على رأس الحليمات الفطرية بالغشاء المخاطي الظهري للسان .و أيضا أظهرت الجمال والأرانب براعم التذوق فى حليمات التذوق التقليدية باللسان مع عدم وجود الحليمات الورقية في الجمال. بالاضافة لكل ذلك قد كانت نتائج الدجاج و الإبل مناعيًا سلبيَّة فى النتائج الهيستوكيميائسة المناعية للجسم المضاد لمستقبلات الميتاتروبيك غلوتامات ـ ع ؛ وكانت نتائج كلا من الضفادع و الأر انب مناعيًا إيجابية مع أقوى تفاعل في الأر انب. الاستتتاج: ومما سبق تم إستتناج أن هناك ارتباط مباشر بين متغير ات التركيب النسيجي للغشاء المخاطي الظهري للسان وبين العو امل البيئية المختلفة والذي من شأنه أن يعكس قدرة الغشاء المخاطي الظهري للسان على التكيف. 